

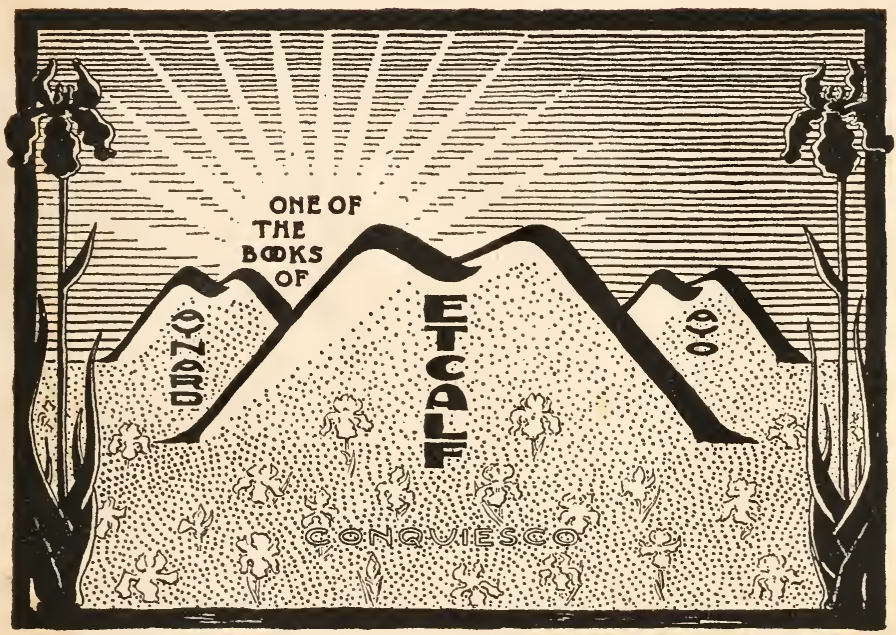



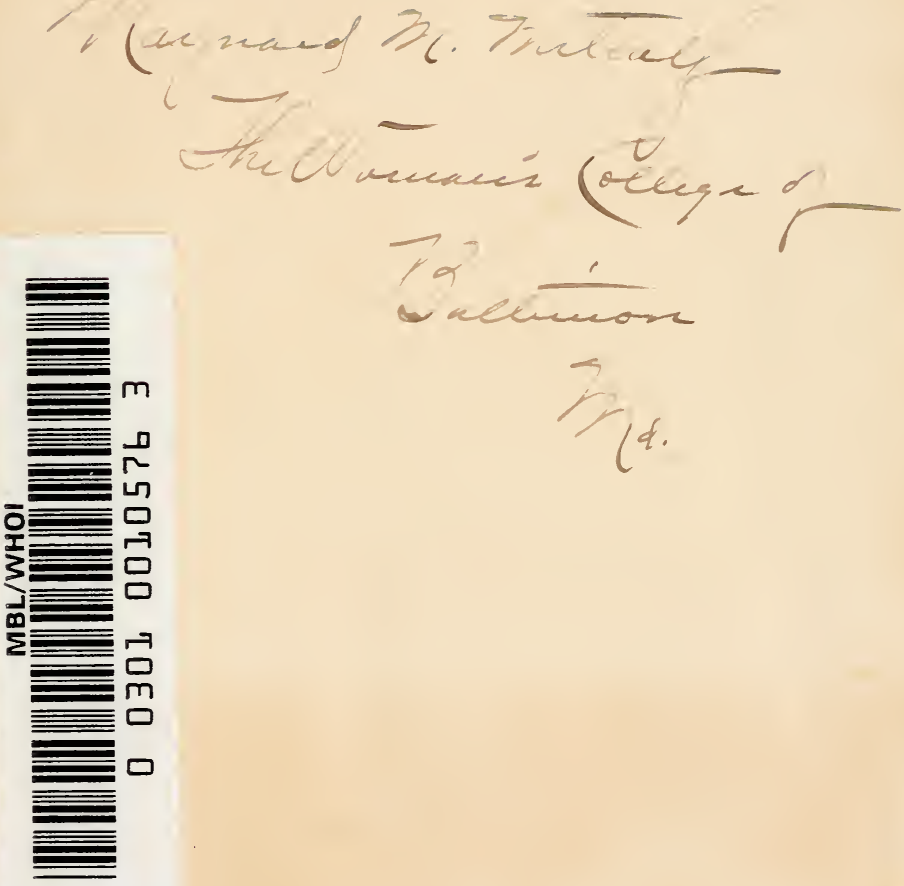


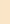





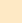


THE

BIOLOGICAL PROBLEM OF TO-DAY

H E R T W I G 


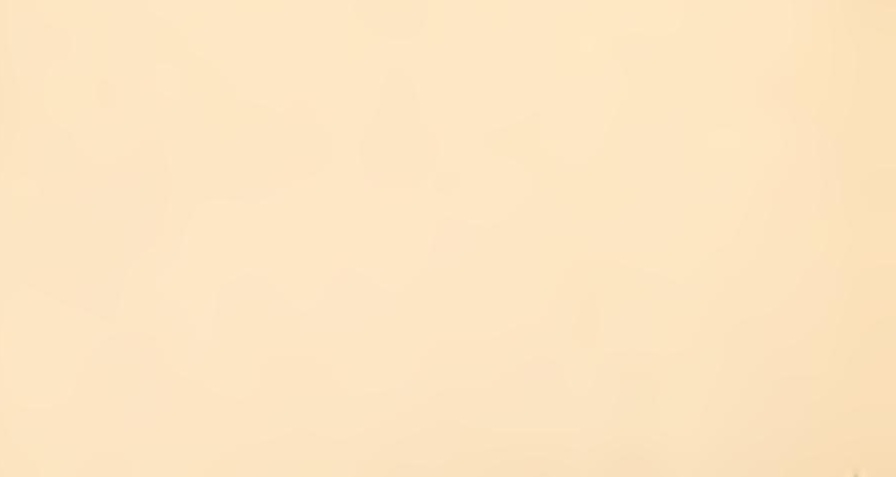




\section{THE BIOLOGICAL PROBLEM OF TO-DAY}

PREFORMATION OR EPIGENESIS?

THE BASIS OF A THEORY OF ORGANIC DEVELOPMENT

BY

\section{PROFESSOR DR. OSCAR HERTWIG}

DIRECTOR OF THE SECOND ANATOMICAL INSTITUTE OF THE UNIVERSITY OF BERLIN

Zuthorized Translation

BV

P. CHALMERS MITCHELL, M.A.

WITH AN INTRODUCTION BY THE TRANSLATOR AND A GLOSSARY OF THE TECHNICAL TERMS

TH E M ACMIL L A N C O. NEW YORK 



\section{PREFACE}

ShortLy after the appearance of Dr. Oscar Hertwig's treatise 'Präformation oder Epigenese?' I published in Natural Science (1894) a detailed abstract of it. But the momentous issues involved in the problem of heredity, and the great interest excited by Dr. Weismann's theories, make it desirable that a full translation should appear. By the kindness of Dr. Hertwig and his German publisher, this is now possible. I have prefixed an introduction, written for those who are interested in the general problem, but who have little acquaintance with the technical matters on which the argument turns. In the actual translation I have tried no more than to give a faithful rendering of the German. After no little perplexity, I have rendered the German word Anlage as 'rudiment.' It is true, a double meaning has been grafted upon the English word, and it is widely employed to mean an undeveloped structure, without discrimination between incipient and vestigial character. I use it in the etymological sense, as an incipient structure. For the difficult words, Erbgleich and Erbungleich, a succession of new terms have been suggested. Here I use for the first term the word ' doubling,' for the second 'differentiating.' 



\section{TRANSLATOR'S INTRODUCTION}

INQUIRY into the problems of heredity is beset with many difficulties, of which not the least is the temptation to argue about the possible, or the probable, rather than to keep in the lines of observation. Setting out from a laborious and beautiful series of investigations into the anatomy of the Hydromedusæ, Weismann came to think that the organic material from which the sexual cells of these animals arose was not the common protoplasm of their tissues, but a peculiar plasm, distinct in its nature and possibilities. In the course of several years, Weismann not only continued his own investigations in the many directions that his conception suggested, but made abundant use of that new knowledge of the nature and properties of cells which has been the feature of the microscopy of the last decade. His theory of the germplasm gradually grew, undergoing many alterations, so that even in its present form he regards it as tentative. Neglecting the numerous modifications and accessory hypotheses by which he has sought to adapt the theory to the phantasmagorial complexity of organic nature, the main outline of the theory is 
as follows: A living being takes its individual origin only where there is separated from the stock of the parent a little piece of the peculiar reproductive plasm, the so-called germplasm. In sexless reproduction one parent is enough; in sexual reproduction equal masses of germplasm from each parent combine to form the new individual. The germplasm resides in the nucleus of cells, and Weismann identifies it with the nuclear material which microscopists have named chromatin, on account of the avidity with which it absorbs certain dyes. Like ordinary protoplasm, of which the bulk of cell-bodies is composed, the germplasm is a living material, capable of growing in bulk without alteration of structure, when it has access to appropriate food. But it is a living material much more complex than protoplasm. In the first place, the mass of germplasm which is the starting-point of a new individual consists of several, sometimes of many, pieces termed $i d s$, each of which contains all the possibilities-generic, specific, individual —of a new organism. Each $i d$ is a veritable microcosm, possessed of a historic architecture that has been slowly elaborated during the multitudinous series of generations that stretch backwards in time from every living individual. This microcosm, again, consists of a number of minor vital units called determinants, which cohere according to an orderly plan. A determinant exists for every part of the adult organism which is capable of being different in different individuals. And, lastly, each determinant consists of a number of ultimate particles 
called biophores, which eventually pass into the protoplasm of the cells in which they come to lie and direct the vital activities of these cells. A most important part of the theory is what it supposes to occur during the embryological development of the individual. The mass of germplasm derived from the germplasm of the parent lies in a mass of ordinary protoplasm. Both the protoplasm and the germplasm, by the assimilation of food, gradually increase in bulk until the adult size of the organism is reached. Along with the increase of size there occurs a gradual specialisation, during which the tissues, organs, and structure of the creature are attained. The simplest conception of this process is to regard the initial mass as a single cell, the nucleus of which is composed of the parental germplasm. The nucleus and the protoplasm increase in size, and then, first the nucleus and next the protoplasm divide, so that there are formed two cells, each with a nucleus. Each of these again divides, and the process goes on continuously, the new-formed cells gradually being marshalled into their places to form the adult tissues and organs, and they gradually assume the special characters of these tissues and organs. Now, Weismann's theory supposes that the first division of the germplasm is what is called in this translation a doubling division (Erbgleiche Theilung). The mass has grown in bulk, without altering its character, so that each resulting mass is precisely like the other. One of the two portions subsequently increases in bulk, and may again 
divide repeatedly, but always by doubling division. It therefore remains unaltered germplasm, and eventually is marshalled to the part of the adult from which new organisms are to arise, becoming, for instance, in the case of a woman, the nuclear matter of the ovary. Thus, the germplasm is handed on continuously from generation to generation, forming an unbroken chain, through each individual, from grandparent to grandchild. This is the immortality of the germ-cells, the part of the theory which has laid so strong a hold on the popular imagination. And with this also is connected the equally celebrated denial of the inheritance of acquired characters. For, at first, it seemed a clear inference that, if the hereditary mass for the daughters were separated off from the hereditary mass that was to form the mother, at the very first, before the body of the mother was formed, the daughters were in all essentials the sisters of their mother, and could take from her nothing of any characters that might be impressed upon her body in subsequent development. As this treatise touches only indirectly upon the question of acquired characters, it is necessary only to mention that while his early sharp denial of the possibility of inheritance of acquired characters has led to a damaging criticism of supposed cases, Weismann, in the riper development of his theory, has found a possibility for the partial transference of influences that affect the mother to the germplasm contained within her.

It is with the fate of the other portion coming 
from the first division of the germplasm that we are concerned here. It is set apart to form the nuclear matter, and so to control the building up of the actual individual. Weismann supposes that the subsequent divisions it undergoes are what I call in this translation differentiating divisions (Erbungleiche Theilung). According to his theory, in each of these divisions the microcosms of the germplasm are not doubled, but are slowly disintegrated, the division differentiating among the determinants, and marshalling one set into one portion, the other set into the other portion. 'The differentiating process occurs in an order determined by the historic architecture of the microcosms, so that the proper determinants are liberated at the proper time for the modelling of the tissues and organs. Ultimately, when the whole body is formed, the cells contain only their own kind of determinants. It follows, of course, from this that the cells of the tissues cannot give rise to structures containing less disintegrated nuclear material than their own nuclear material, and least of all to reproductive cells, which must contain the undisintegrated microcosms of the germplasm. As special adaptations for the formation of buds and for the reconstruction of lost parts, cells may be provided with latent groups of determinants to become active only on emergency. But with these exceptions, the nuclear matter of the cells of the body contains only what is called idioplasm, a differentiated portion of the germplasm peculiar to cells of their own order, and it can give rise only to 
idioplasm of the same or of a lower order. And here we come round again to the original observations from which Weismann set out. For he found that among the Hydromedusæ, although the sexual cells seemed to arise in very different topographical positions, there had always been a migration to these localities of a material which he would now call the germplasm. And here also, that the point may be made plain, there may be mentioned the observations of surgeons and physicians, who insist that the growths of disease always conform strictly, in their cellular nature, to the tissues from which they arose, and that in the healing of wounds like only grows from cellular like.

Dr. Oscar Hertwig is a scientific naturalist of the very first rank, and his name is peculiarly associated with many of the most important advances in our knowledge of cells and of embryology. To him chiefly, for instance, is due the discovery of the intimate nature of fertilisation-that it consists in the union of the nuclear matter of a cell from the male with the nuclear matter of a cell from the female. With the exception of Francis Balfour, no man has laboured more patiently, or achieved more wonderful results, in the investigation of the origin and marshalling of cells by which the egg changes into the adult. From his own experience, and from his study of the observations made by others, he has been led to doubt the validity of apparently fundamental parts of Weismann's conception. In the first place, he thinks that there is no evidence for the existence of differentiating as opposed to 
doubling divisions, and that there is evidence that divisions always are doubling divisions. He thinks, in fact, that when a portion of germplasm divides, the daughter-cells receive portions of germplasm exactly alike and exactly like the original portion in the parent-cell. The cells, indeed, become different from each other as the organism grows, some becoming muscle-cells, others nerve-cells, others digestive-cells, and so forth. Weismann thinks that the differences occur because, in the disintegration of the germplasm-microcosms, according to a prearranged plan, only the determinants for nerve-cells are marshalled into nervecells, only those for muscle-cells into muscle-cells, and so forth. The development is an evolution, an unfolding or unwrapping of little rudiments that lie in the germplasm. Hertwig insists that every cell receives the same kind of germplasm, but that, according to the situations in which they come to lie, different characters are impressed upon them. The development is an epigenesis, or impressing on identical material of different characters by different surrounding forces. His second line of argument against Weismann leads to a similar conclusion. A large number of the characters that arise in an organism during its development are due to the combination of many cells. They cannot come into existence until the multiplication of cells has made their existence possible, and he thinks, therefore, that they cannot have rudiments inside a single cell as their determining cause.

It is no part of my present purpose to insist, 
even to the extent that in this treatise Hertwig nimself insists, upon the points of agreement between the two views. We are only at the beginning of inquiry into the problems of heredity, and the protagonists of the opposing views, like all those who care more for knowledge than for argument, are concerned more for truth than for the establishment of a modus vivendi. Reconciliation is the parent of slothful thinking and of glosses ; it is by sharp contrasting of the opposing views that we are like to have new facts elicited, and new lines of inquiry suggested.

As many are interested in the problems who have little acquaintance with the technical facts of embryology, a simple account of the early stages in the development of an animal may be useful for reference. I shall choose back-boned animals, as, from the inclusion of man among them, they are of more general interest. The process begins with the fertilisation of the egg-cell by the fusion with its nucleus of the nucleus or head of a male-cell or spermatozoon. At their first origin the nuclei of the sperm and of the egg may be of very different appearance, while that of the sperm is invariably smaller than that of the egg. But before or during the process of fertilisation, changes take place, the result of which is that the fusing nuclei are exactly alike in morphological character. The chromatin, or peculiar substance of the nuclei, is transformed into a number of bodies known as chromosomes, which are of the same number, form, and size, in the two sexes. 
Form, size, and number are different in different animals, but there is reason to believe that they are normally the same in all the individuals of a species. The fertilised nucleus, thus consisting of chromosomes from male and female, then divides by a complicated process known as karyokinesis, in which each chromosome splits longitudinally, one half passing to each daughter-nucleus. Throughout the whole process of embryonic and postembryonic growth, the chromatin is gradually increasing in bulk, and being distributed by karyokinesis. The normal character of these divisions is as follows: A daughter-nucleus, after separation, passes through a resting phase, in which the chromosomes, as definite structures, disappear, and in which growth of the nuclear matter occurs. Then chromosomes of definite size and form, and corresponding in number to those present in the fertilised egg-cell, again appear. These split longitudinally, and a half of each passes to each daughter-nucleus. The similarity of these processes among all living creatures, vegetable and animal, and their extreme complication, suggests that karyokinesis is the chief factor in distributing the hereditary mass to the growing organism. Weismann and some others think that there is evidence for a difference in the nature of the process, which may in some cases correspond to his distinction between doubling and differentiating divisions, but it may be said at once that the record of observations is yet too conflicting for any such general interpretation. 
Along with the increase in bulk and distribution of the nuclear matter, there goes an increase in bulk and segregation of the ordinary protoplasm. The simplicity of the actual development of most back-boned animals is disguised by provision for the nutrition of the growing embryo. In a large number of cases, as, for instance, in birds and reptiles, the egg-cell, a microscopic structure at its first formation, is bloated out into the large eggs with which we are familiar, by the addition of quantities of food-yolk. These eggs, although morphologically single cells, do not divide as cells. A small disc of protoplasm, surrounding the nucleus, floats upon the surface of the yellow yolk, and, when the nucleus divides, furrows appear in this between the daughter-nuclei, but stretch very little way into the inert food-yolk. The subsequent marshalling of the cells is disguised by their association with a preponderating mass of inert material. In a far-distant period in the history of evolution, the eggs of mammals like man were large, and contained, as in the lowest existing mammals, a store of food-yolk. Now the foodyolk is not formed, as the developing embryo obtains its nourishment from the blood of the mother. But the course of development is distorted, partly as a legacy from the old large-yolked condition, and still more to suit the new method of nutrition. Some of the simpler animals even among existing vertebrates still exhibit a marshalling of cells common among invertebrates, and to be traced under the complications of higher forms. 
In these, now, as in the marine ancestors of all the vertebrates, the fertilised egg is a tiny cell provided with very little yolk, and set adrift in the seawater. The first division of the nucleus, and each subsequent division of the daughter-nuclei, is at once followed by division or segmentation of the whole cell. The plane between the two cells thus formed is called the first cleavage-plane, and is regarded as vertical. The second cleavage-plane is at right angles to the first, and is also vertical, so that the little embryo consists of four cells, all on the same horizontal plane. The third cleavageplane is horizontal, and divides the four cells into an upper and lower tier of four cells. In the course of a series of divisions the eight cells come to form a hollow sphere-the blastosphere-enclosing a cavity known as the cleavage or segmentation cavity.

The first great modelling then occurs. At one side the single layer of cells, of which the wall of the blastosphere is composed, begins to bend inwards, just as a dimple forms in a hollow indiarubber ball if a pin-prick allow some of the contained air to escape. Further cell-divisions occur, and the invagination becomes deeper, until the invaginating wall nearly touches the wall which has retained its primitive position. The embryo has thus become a hollow cup, the walls of which are double. The cup elongates, and its mouth, originally wide open, becomes more and more narrow, until it forms a small pore opening into an elongated blind sack. The embryo in this stage is known as 
a gastrula. The central cavity becomes the cavity of the gut; the pore leading into it marks the hind end of the future animal, in the case of vertebrates, and is known as the blastopore. The layer of cells lining the cavity of the sack is known as the hypoblast, and gives rise chiefly to the cells lining the alimentary canal of the future animal. The outer layer of cells is known as the epiblast, and forms the outer layer of the skin, and, along the future dorsal line, gives rise to the nervous system. The muscles and skeleton and the reproductive cells arise from a set of cells known as the mesoblast, that are formed chiefly from the hypoblast, and that push their way in between the hypoblast and epiblast.

This general course of development may be traced in all members of the vertebrate group, and, with slight modifications, may be applied to a large number of invertebrates. As the modelling of the general contour of the whole body and of the separate organs proceeds, the protoplasm of the cells gradually assumes the characters of the substance of muscle-cells, liver-cells, nerve-cells, bloodcells, and so forth. The problem of this book will become clearer if it be considered with special reference to what goes on in these early stages. Hertwig says that all the cells of the epiblast, hypoblast, mesoblast, and of the later derivatives of these primary layers, receive identical portions of germplasm by means of doubling nuclear divisions. The different positions, relations to each other and to the whole organism, and to the 
environment in the widest sense of the term, cause different sides of the capacities of the cells to be developed, but they retain in a latent form all the capacities of the species. Weismann says that the nuclear divisions are differentiating, and that the microcosms of the germplasm, in accordance with their inherited architecture, gradually liberate different kinds of determinants into the different cells, and that, therefore, the essential cause of the specialisation of the organism was contained from the beginning in the germplasm. 



\section{CONTENTS}



WEISMANN'S THEORY OF THE GERMPLASM AND DOCTRINE

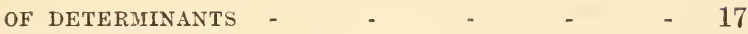
PART II.

THOUGHTS TOWARDS A THEORY OF THE DEVELOPMENT OF ORGANISMS - 101 

THE

\section{BIOLOGICAL PROBLEM OF TO-DAY}

\section{INTRODUCTION.}

Wнат is development? Does it imply preformation or epigenesis? This perplexing question of biology has reappeared recently as a problem of the day. Of late years there have been set forth contradictory doctrines, each seeking to explain the process by which the fertilised egg-cell, an apparently simple beginning, gives rise to the adult organism, which often is exceedingly complicated, and which has the capacity of producing new beginnings like that from which it itself arose.

The opposing views of to-day were in existence centuries ago, and they are known in the history of science as the theory of preformation or evolution, and the theory of epigenesis. That most of the great biologists of the seventeenth and eighteenth centuries were decided upholders of evolution was the natural result of the contemporary knowledge of facts. For they knew only the external signs of the process of develop- 
ment. All they saw was the embryo becoming adult, the bud growing out into a blossom, as the result of a process in which nutrition transformed smaller to greater parts. And so they regarded development as a simple process of growth resulting from nutrition. Their mental picture of the germ or beginning of an organism was an exceedingly reduced image of the organism, an image requiring for its development nothing but nutrition and growth. That the material eye failed to recognise the miniature they attributed to the imperfection of our senses, and to the extreme minuteness and resulting opacity of the object.

That it might satisfy our human craving for final causes, the theory of preformation had to be accompanied by a corresponding explanation of the origin of the miniatures. Biologists had already abandoned the error of such spontaneous generation as the origin of flies from decaying meat, and, in its place, had accepted the doctrine of the continuity of life, formulating it in the phrase, Omne vivum e vivo (Each life from a life), and in the similar phrase, Omne vivum ex ovo (Each life from an egg). One creature issued from another, within which it had lain as a germ, and the series was continuous. Thus, the theory of preformation gave rise to the conception that living things were a series of cases or wrappings, germ folded within germ. The origin of life was relegated to the beginning, at the creation of the world : it became the work of a supernatural Creator, who, when $\mathrm{He}$ formed the first creatures, formed with them, and 
placed within them, the germs of all subsequent creatures.

To reckon at their proper value the theory of preformation, and, still more, the doctrine of enfolded germs, the standard of appreciation must not be the present range of our knowledge. They must be viewed historically, in the light of the knowledge of these days.

Nowadays it is not so much pure reason as a wider empirical knowledge of nature, with its consequent transformation of ideas, that makes the doctrine of enfoldment difficult. Abstract thought sets no limit to smallness or greatness; for mathematics deals with the infinitely small and with the infinitely great. So long as actual observation had not determined the limits of minuteness in the cases in question, there were no logical difficulties in the doctrine of enfolded germs. The biology of earlier centuries had not our empirical standard. What appeared then to be a simple organic material we have resolved into millions of cells, themselves consisting of different chemical materials. The chemical materials have been analysed into their elements, and chemistry and physics have determined the dimensions of the ultimate molecules of these. It is only because the minute constitution of matter is no longer a secret to us that the theory of germ within germ now touches the absurd.

It was very different in earlier days; the acutest biologists and philosophers were evolutionists, and an epigenetic conception of the process of develop- 
ment could find no foothold alongside the apparent logical consistency of the theory of preformation.

Wolff's Theoria Generationis (1759) failed to convince his contemporaries, because he could bring against the closed system of the evolutionists only isolated observations, and these doubtful of interpretation; and because, in his time, on account of the rudimentary state of the methods of research in biology, men attached more importance to abstract reasoning than to observation. His effort was the more praiseworthy in that it was observation bearing witness against abstract and dogmatic conceptions. By means of actual observation he tried to expose the fallacy in preformation, to show that the organism was not fully formed in the germ, but that all development proceeded by new formation, or epigenesis; that the germ consisted of unorganised organic material, which became formed or organised only little by little in the course of its development, and that Nature really was able to produce an organism from an unorganised material simply by her inherent forces.

It is interesting to display the essential contrast between preformation and epigenesis in the poetical words of Wolft' himself. 'You must remember,' so run his words in the second argument against the probability of preformation, 'that an evolution would be a phenomenon formed in its real essence by God at the Creation, but created in condition invisible, and so as to remain invisible for long before it would become visible. See, then, that a phenomenon of enfolding is a miracle, differing 
from ordinary miracles only in these: first, it was at the creation of the world that God produced it; second, it remained invisible for long before it became visible. In truth, therefore, all organic bodies would be miracles. Would not this change for us the presence of Nature? Would it not spoil her of her beauty? Hitherto we had a living Nature, displaying endless changes by her own forces. Now it would be a fabric displaying change in seeming only, in truth and essence remaining unchanged and as it was constructed, save that it gradually becomes more and more used up. Formerly it was a Nature destroying herself and creating herself anew, only that endless changes might become visible and new sides be brought to light. Now it would be a lifeless mass shedding off piece after piece until the stock should come to an end.'

None the less, who seeks in Wolff's 'Theoria Generationis' an account of the means or forces by which Nature builds up organic forms will seek in vain. The vis essentialis (inherent force) with which Wolff endowed his plastic organic material, or the nisus formativus (formative force), afterwards suggested to science by Blumenbach - what are they but empty words by which men seek to grasp in thought what has eluded them? Wolff's epigenesis was not a complete explanation - indeed, from its fundamental conception it could not possibly be such. For investigation of the natural forces by which development proceeds can advance only slowly and step by step, and for long will con- 
stitute the foremost task of biology. The prosecution of biological investigation will continuously endow the theory of epigenesis with a fuller and fuller meaning, but will never transform it into a solution final in the sense of the theory of preformation.

It seems to me that the significance of Wolff's doctrine lies in this: it rejected the purely formal theory of preformation because actual observations were against it. Thereby $\mathrm{Wolff}$ freed research from the straitened bonds of prejudice, and entered the only possible path by which science can advance - the path along which the biology of our century has made so great advances.

Biologists of to-day approach the problem of organic development equipped with incomparably greater knowledge and with more delicate methods of research. But in our thoughts to-day, as we discuss the essential nature of the process of organic development and the mutual causal relations between rudiments and their products, the same contradictory views are present, altered only as our methods of expression have altered.

In a striking fashion Roux ${ }^{1}$ has contrasted the opposing ideas inherent in our modern conception of development, but yet identical with those which formerly found expression in the theories of preformation and epigenesis.

"By the term "embryonic development," in its

1 Wilhelm Roux in Zeitschrift für Biologie, vol. xxi. (1585): Zïr Orientirung veber einige Prolileme der Entryonuleir Enturicklung. 
ordinary acceptation, we understand the appearance of visible complexity. But when we speak of the visibility of the resulting complexity, we use a subjective term, the value of which is relative to the human eye. Going further into the matter, we must break up the conception into two parts, and distinguish between the actual production of complexity and the mere transformation of complexity from a condition invisible to us into complexity visible to our senses.

'The two kinds of development I have indicated bear a relation to each other that recalls the old opposing doctrines of preformation and epigenesis, the alternatives of a time when it was a taskperhaps the only possible task-to record the completed results of the stages in development as they became complete-in fact, to record the externally visible changes of shape. In this descriptive investigation of the development of external form, epigenesis, the successive formation of new shapes, gained a complete victory over evolution, the mere becoming visible of pre-existing details of shape.

'The closer investigation of embryonic development that is necessary in a search for causes brings us once more against the old alternatives, and compels us to a closer scrutiny of them.

'In this, if we still retain the old terms, epigenesis would mean not merely the building up of complicated form through the agency of a substratum, apparently simple, but perhaps with an extraordinarily complicated, minute structure, but, in the strictest sense of the term, the new formation of 
complexity, an actual increase of complexity. Evolution, on the other hand, would imply the mere becoming visible of pre-existing latent differentiation. Clearly, according to these general definitions, occurrences which outwardly exhibit epigenesis may be in reality partial or complete evolution. In fact, the deepest consideration leads us again to the original question: Is embryonic development epigenesis or evolution? Is it the new formation of complexity, or is it the becoming visible of complexity previously invisible to us?'

Thus, in our own days, after the controversy has been at rest for long, biologists are assembled in opposing groups, one under the standard of epigenesis, another under that of preformation.

Weismann ${ }^{1}$ leads the van for preformation; for the last ten years he has occupied himself with the theoretical discussion of the questions set forth above; and now, in a recent treatise, The Germplasm, he has combined his views, already many times modified, in a coherent theory. Now he explains candidly that he has been driven to the view that epigenetic development does not exist. 'In the first chapter of my book,' he remarks, 'will be found an actual proof of the reality of evolution, a proof so simple and obvious that I can scarcely understand to-day how it could have escaped my notice so long' (Germplasm, p. 14). Elsewhere he writes: "I believe that I have established that

1 See Weismann's Collected Essays, Clarendon Press (2nd edit.), vol. i., 1891, vol. ii., 1892 ; and Weismann's Germplasm, Walter Scott's Contemporary Science Series; 1893. The references in this translation are to the latter volume. 
ontogeny can be explained only by evolution, and not by epigenesis.'

A mental process, which consciously or unconsciously plays a great part with evolutionists, and helps to determine their conclusions, is characteristic of the direction of their inquiries. They set out from the fact that the characters of the parents, often to the smallest detail, are transmitted to children by means of the germ or rudiment; they conclude that the active causes of all the complexity that arises must be contained in the apparently homogeneous germ, embryological differentiation being a spontaneous process. It follows that the apparent homogeneity is, in reality, latent complexity which becomes patent during the progress of ontogeny. Latent complexity implies a material substratum, consisting of actual particles for which many different names have been found. As our senses can give us no experimental knowledge of these particles, which are so small as to be invisible, modern evolutionists attempt to picture them, in imagination, by reflecting all the visible characters of the perfected organism upon the undivided egocell, so peopling that globule of yolk with a system of minute particles corresponding in quality and in spacial arrangement with the larger parts of the adult.

Weismann has practised this art in the true spirit of a virtuoso, and has elaborated it into a novel morle of biological investigation. Take anexample;'It would be impossible,' he says in The Germplasm (p. 138), 'for any small portion of the human skin 
to undergo a hereditary and independent change from the germ onwards, unless a small vital element corresponding to this particular part of the skin existed in the germ substance, a variation in this element causing a corresponding variation in the part concerned. Were this not the case, birthmarks would not exist.'

Thus, in a slightly altered fashion, we come again to the position of the evolutionists of last century, for whom the germ was an extremely small miniature of the adult creature. The new evolution, as Weismann in especial has established it, seems to me to differ from the old doctrine only in two important points; and these must be placed to the credit of the greater scientific knowledge of our century. The first point concerns the relative positions of the parts in the patent and latent conditions. The older evolutionists assumed that these were identical, that the germ was a true miniature. It is true that Weismann regards his almost countless germinal particles as being held together in an architectural structure of almost inconceivable complexity. For him the germ is an exceedingly complicated living being, a microcosm in the truest sense, in which every independently variable part that ever appears throughout the whole life is represented by a living particle, and in which each of the living particles is endowed with a definite, inherited position, a constitution, and the power of rapid multiplication. It is upon the qualities of these ultimate particles that he makes depend the qualities of the corresponding parts of 
the adult, the parts that are cells as well as the parts built of many cells. As, however, during visible development, the parts of the embryo undergo many changes of position and metamorphoses, Weismann is compelled to make the assumption that the germ, as a micro-organism, is not simply a miniature of the adult, but that its minute particles have an arrangement totally different from that of the corresponding parts in the adult organism.

The second point is the origin of each new generation. To explain the continuity of development, the old evolutionists held that the generations lay enfolded one within another. Weismann avoids this difficulty by endowing his germs with divisibility, but he gives us no proof that division could possibly take place in the case of structures composed of innumerable particles built up into a definite and most complicated architectural system.

Although the new evolution differs from the old in the points mentioned above, the two theories obviously agree very closely in the nature of their arguments and conclusions. When, to satisfy our craving for causality, biologists transform the visible complexity of the adult organism into a latent complexity of the germ, and try to express this by imaginary tokens, by minute and complicated particles cohering into a system, they are making a phantasmal image which, indeed, apparently may satisfy the craving for causality (to satisfy which it was invented), but which eludes the control of concrete thought, by dealing with a complexity 
that is latent, and perhaps only imaginary. Thus, craftily, they prepare for our craving after causality a slumbrous pillow, in the manner of the philosophers who would refer the creation of the world to a supernatural principle.

But their pillow of sleep is dangerous for biological research: he who builds such castles in the air easily mistakes his imaginary bricks, invented to explain the complexity, for real stones. He entangles himself in the cobwebs of his own thoughts, which seem to him so logical, that finally he trusts the labour of his mind more than Nature herself.

'Experiment,' says Weismann in The Germplasm, 'is not the only way to reach general views, nor is it always the safest means of discrimination, although at first it seems conclusive. . . . It seems to me that in this case we can draw more prudent conclusions from the general facts of inheritance than from the results of experiments that are neither quite clear nor undubious, although in themselves they are most valuable, and deserve the most careful consideration. If one remembers what was said in my section on the architecture of the germplasm as the basis of the theory of determinants, it will be agreed with me that ontogeny must find its explanation in evolution, and not in epigenesis.'"2

I take up a more epigenetic position, and years ago I attacked evolutionary doctrines in many of 
their modifications. ${ }^{1}$ Thus, in the Studien zur Blätter Theorie, published by Richard Hertwig and myself, I combated the supposed law that the germinal layers histologically were primitive organs. Next, in a pamphlet entitled The Problem of Fertilisation: a Theory of Heredity, I attempted to disprove the principle of His that there were organ-building foci in the germ. In my treatise On Ovogenesis and Spermatogenesis in the Nematodes, I declared against the suppositions involved in Weismann's doctrine of the germplasm, and sharply distinguished the theory, simultaneously propounded by Strasburger and myself,

1 The ideas expressed in this book may be found, in an elementary condition, in various publications of my own, and written in conjunction with my brother, Richard Hertwig: Oscar and Richard Hertwig, Die Actinien ; Jena, 1879 (pp. 203-217). Oscar Hertwig, Des Problem der Befruchtung und der Isotropie des Eies, eine Theorie der Vererbung; Jena, 1884. Oscar Hertwig, Vergleich der Ei-und Semenbildung bei Nematoden, Areh. f. Hikrosk. Anatomie, vol. xxxvi., 1890, pp. 77-128. Oscar Hertwig, L'muned und Spince bifida, Arch. f. Mikrosk. Anatomie, vol. xxxix., 1892, pp. 476-492. Oscar Hertwig, Aeltere und, nevere Entuicklungstheorien; Berlin, 1892. Osear Hertwig, The Cell: Sonnenschein; London, 1895. Oscar Hertwig, Ueber den Werth der ersten Furchungsellen für die Organbildung des Embryo, Arch. f. Mikrosk. Anatomie, vol. xlii., 1893. The chief other writers to whom I refer are: Herbert Siencer, Principles of Biology. Darwin, Pangenesis, a Prorisional Hypothesis (in Variation of Plants and Animals under Domestication). Haeckel, Die Perigenesis der Plastidule. Weismann, Zoc. cit., p. 8. Naegeli, Alechanisch-physiologische Theoric der Abstanmungstehre; Hünchen, 1884. Strasburger, Neue Lntersuchungen ueber den Befruehtungsvorgang bei den Phanerogamen als Grundlage für eine Theorie der Zeugung, 1884. H. de Vries, Intracellulare Pangenesis. W. His, Unsere Körperform und das physiologische Problem ihrer Entstehung, 1874. W. Roux, loc. cit., p. 6. Driesch, loc. cit., 1. 48. 
that the nucleus is the bearer of the hereditary material, from the evolutionistic interpretation given it by Weismann.

A paper on 'The Blastopore and Spina Bifida,' and an occasional lecture on 'Old and New Theories of Development,' gave me the opportunity of dealing with Roux's mosaic theory, although that not only shows learning, but apparently is the outcome of experiment. I advocated in its place the theory that ' the embryological development of an organism is no mosaic work. The parts of an organism develop in relation to each other, the development of a part depending upon the development of the whole.' The labours of Roux, as well as the valuable researches of Driesch, induced me to carry out a series of experiments with the object of getting a surer basis for my epigenetic conception of development. The results of these were published recently under the title, On the Value of the First Cleavage-cells in the Formation of the Organs of Embryos.

In the latter treatise I confined myself advisedly to the exposition and interpretation of the results of my investigations, having in view a subsequent discussion of the more theoretical bearings of my results. It is this that sees the light in the present book.

As for many years I have occupied myself with the problem of development, pursuing observation and framing theory, there is due to myself and to others an exposition of the position I have assumed in many of my treatises, but in a more connected 
and elaborated fashion than has been possible hitherto. This course is the more imperative, as in his recent magnum opus on the germplasm Weismann has propounded a theory of evolution wrought with the greatest care and acuteness, and totally irreconcilable with my conclusions. The chief differences between my views and those of Weismann have now become clearer and more tangible than ever. It is true that in my textbook, On the Structure and Function of Cells, ${ }^{1}$ published in the autumn of 1892, I gave a short account of my theory of heredity in chapter ix., 'The Cell as the Material Beginning of the Organism.' But in that I could not deal with Weismann's work, which appeared simultaneously, and, moreover, in a text-book it was impossible to do more than sketch my views.

My present task is twofold; it has both a positive and a negative side. First, I have to examine the arguments recently alleged in favour of the theory of preformation, testing them to reveal their inherent weaknesses, and to controvert their fallacies. As Weismann unquestionably is the chief of those who have adrocated preformation, and has made a closed system of it again, it is necessary for me to take special notice of his conception as it is set forth in The Germplasm. Although I am no friend of polemic, the case demands it. For the decision of a question so momentous as the relative scopes of evolution and epigenesis in embryology must

${ }^{1}$ An English translation, The Cell, was published by Swan Sommenschein and Co. in 1895. 
have an important bearing on the future of biology, upon its aim and the method of research.

But criticism of Weismann's hypothesis is not to be an end in itself; I am more anxious to show the lines upon which, as I think, the real meaning of the process of organic development will come to be learned. In a second section, therefore, I shall explain my own views in greater detail, and, as I hope, place them on a firmer foundation than formerly was possible. 


\section{PART I.}

WEISMANN'S THEORY OF THE GERMPLASM AND DOCTRINE OF DETERMINANTS.

As may be seen in his essays, On Life and Death, On the Duration of Life, etc., Weismann believes himself to have established a fundamental distinction between unicellular and multicellular organisms. Unicellular organisms (he would have it) do not undergo natural death, but, since they are able to reproduce themselves continuously by a process of simple division, are immortal. Multicellular organisms, on the other hand, must perish after a definite duration of life, and so are mortal. He makes an exception of the sexual cells, which, like unicellular organisms, are able to multiply indefinitely, and so are immortal. Thus Weismann came to make a distinction between the mortal (somatic) cells and the immortal (germ) cells of multicellular organisms. The latter he regarded as arising directly from the egg-cell, and never from somatic cells.

Nussbaum has given utterance to similar views, holding that the dividing egg at a very early period cleaves into the cells from which the individual 
grows and the cells for the maintenance of the species. He has enunciated the proposition that, when the sexual cells have been separated from the cells of the young embryo, the material of the germ has been divided into shares for the individual and shares for the species; that the sexual cells take no part in the formation of the body, and that body-cells never give rise to ova or spermatozoa.

Weismann differs from Nussbaum in one important point. He lays no stress on the direct origin of the sexual cells, as cells, from the egg at the beginning of its development. He found, for instance, that, in the case of hydroids, the sexual cells did not arise in such a fashion. He considers, therefore, that the chain of events is as follows: The whole of the protoplasm of an egg-cell is not required to build up the new being, and the superfluous part remains unaltered to form the sexual cells of the new generation. Unlike Nussbaum, then, he asserts a continuity, not for the sexual cells, but for the germinal protoplasm which he believes to pass along definite cell-tracks until it forms the sexual cells. From this germinal protoplasm, which makes the germ-cells, he distinguishes the somatic protoplasm which makes the mortal, somatic cells.

The germplasm theory entered a new phase in the year 1885, after the independent appearance in 1884 of essays by Strasburger and by me, in which we gave reason for thinking that the cell nucleus was, as I expressed it, the bearer of the characters which were transmitted by parents to their off- 
spring; that, in fact, the nucleus was the material basis of heredity.

Weismann laid hold of this idea, but transmuted it to fit in with his original theory of the germplasm. Shortly put, his view is as follows: The whole of the nuclear material is not hereditary material, but only a definite part is such, and this part, throughout the development of the individual, remains unaltered in composition, and finally becomes the starting-point for the generations to come. The remaining and greater part of the nuclear material does not remain in an unaltered condition. The layers of cells, first formed in the embryo, grow unlike each other, and give rise to different organs and tissues; Weismann draws the inference that the nuclear substance as well alters during the process of development, transforming itself in a regular, orderly fashion, until, finally, each different kind of cell in the whole body contains a specific nuclearplasm. This segregation and transformation begins with the process of cleavage itself, and thus 'the two daughter-cells that arise from the first cleavage of the egg-cell become different, so that the one contains all the hereditary characters for the ectoderm, the other for the endoderm. In further course the ectodermal nuclear-plasm divides into that containing the primary germs of the nervous system, and that containing the similar constituents for the outer skin. By further cellular and nuclear divisions the inherited germs for the nervous system separate into those for the sense organs, those for the central 
nervous system, and so forth, until there are separated the germs for all the separate organs, and for the production of the minutest histological differentiation.'

Weismann calls the diverging nuclearplasms into which the primitive germplasm is gradually transformed histogenous, because they determine the specific characters of the tissues. He assumes that the primitive, original germplasm has a most complicated molecular structure, while the histogenous nuclearplasms for tissue-cells, like muscle-cells, nerve-cells, sense-cells, gland-cells, and so forth, have relatively simpler structures. As, during the growth of the embryo, the germplasm becomes transformed into the histogenous plasms, its molecular structure becomes simpler in proportion to the fewer different possibilities of development each separated portion of it comes to contain.

Following out this chain of ideas, Weismann attributes only to those cells which contain unaltered germplasm the power of giving rise to complete new individuals, while cells with histogenous nuclearplasm, whether these be embryonal cells or cells of the ectoderm or of the endoderm, he regards as having lost this capacity, because nuclearplasm of a simpler molecular structure cannot retransform itself into that with the more complicated structure. The further conclusion is necessary that a part of the nuclearplasm of the original nucleus of the fertilised egg-cell must remain unaltered throughout the various nuclear divisions, although it may be mingled with the 
nuclearplasms of certain series of cells. For these reasons, ova and spermatozoa can arise only when the germplasm which has been handed on from the original nucleus to certain cells is able to overcome the histogenous plasm of these cells. In this respect Weismann has amended his original proposition that the germ-cells were immortal, like unicellular organisms. In a strict and literal interpretation such a proposition would be incorrect, for the germ-cells are immortal only so far as they contain the germplasm, the immortal part of the organism.

In its further elaboration Weismann's conception was influenced considerably by publications of Naegeli, De Vries, and Wiesner. These dealt with the composition of the hereditary material, and they contained new hypotheses concerning the primary structure of the cell-body. Weismann avowedly accepted the suggestion of De Vries, who had rehabilitated and modernized Darwin's doctrine of pangenesis, according to which gemmules, small particles endowed with the power of division, were the material bearers of hereditary characters.

From these different sources Weismann has now worked out, in minutest detail, a theory to which he considers his former writings but as the preface; none the less, he has taken from his own writings the most essential and characteristic sequences of idea, in a fashion but slightly moditied. Let me give the most important parts of his conception.

The substance which is the bearer of the hereditary character of a species (the idioplasm of 
Naegeli) lies not in the general protoplasm of the ovum and spermatozoon, but in their nuclear matter (hypothesis of Hertwig and Strasburger). Weismann calls this the germplasm, so altering the previous connotation of the word. The germplasm of every species has an extremely complicated, stable architecture, an architecture that has been elaborated gradually in the course of past time. In this he distinguishes simple and complex component parts, the biophores, determinants, ids, and idants.

The biophores are his smallest material units, and to them are due the fundamental qualities of life-assimilation, metabolism, and reproduction by division. Thus, they correspond to Herbert Spencer's physiological units, Darwin's gemmules, De Tries' pangenes, and Hertwig's idioblasts. They are the bearers of the various characters of cells, and there are present in the germplasm a very large multitude of different kinds of them, corresponding to the number of cells with different characters.

The determinants are units of the rank next higher; they have qualities of their own, but are composed of groups of several kinds of biophores. They, too, have the power of division which is associated with, and comes about by, multiplication of the coherent company of biophores which lies within them.

The histological character of every cell in a multicellular organism is determined by a single determinant (cell-determinants). Weismann has framed his conception of determinants so as to 
avoid the supposition that every single cell is represented in the germplasm by its own biophores. There are small parts in the body in which the cells are all alike, and for these parts a single determinant suffices, afterwards multiplying by division. On the other hand, each cell or cellgroup in the body, that is independently variable, must have its special determinant in the germplasm. And so the germplasm of a species must possess as many determinants, or guiding particles, as there are in the organism cells or cellgroups that are independently variable in the germ or in later stages (hereditary pieces or determinates).

As every cell or group of cells which corresponds to determinants has a definite position in the body, Weismann infers that the determinants are definitely placed in the germplasm, and form an ordered, complicated community. He has given the name $i d$ to these communities, which are higher units with definite constitution and with complicated architecture. These $i d s$ are bodies containing all the determinants necessary to build up the individual of a species, and correspond to what Weismann previously called ancestral plasms. Every $i d$ must be able to grow and multiply, for it is by their multiplication that the germplasm for new individuals is formed.

A single $i d$ would suffice for the conduct of a single life-history; Weismann, however, in the pursuit of a chain of thought connected with the relation of sexual reproduction to heredity, and 
which I shall not discuss here, regards the germplasm as being still more complicated, and consisting of many, sometimes more than a hundred, ancestral plasms or $i d s$, which have been derived from near or distant ancestors, the peculiarities of whose structures they retain, and may at some time actually produce (explanation of atavism).

But how does this fabric, endowed with an architecture so complicated, actually produce the development of the adult from the egg? The natural mechanism for this purpose is cell division and nuclear division.

According to Weismann's supposition-a supposition which forms, as we shall see, a chief corner-stone of his system-there are two kinds of nuclear division, the difference between which has not been observed, but is a corollary from the difference between their results. The one kind is denoted as integral, or doubling division; the other as differential, or differentiating division. The first method has only an incidental importance in Weismann's hypothesis : it consists of the doubling by growth of the rudiments, and of a perfectly fair division of them between the half-chromosomes; it occurs in tissues-cells, where parent-cells divide into daughter-cells exactly similar to each other and to their parents.

On the other hand, in differentiating division the rudiments become irregularly grouped during their growth; consequently, on division of the ids, which are composed of determinants, totally different combinations of the determinants are included in the 
daughter-ids. This method of division of the germplasm plays the chief part in the transformation of the egg into the adult. It has to take place so that the numberless determinants, or guiding particles, of the germplasm may be disentangled and brought forward at the time and place necessary for them to guide the formations of the determinates, or independently variable parts of the adult body.

To take an example: Weismann's hypothesis requires that when the egg first divides into two, the germplasm should divide into two halves, each containing only one half of the total assemblage of determinants. In each subsequent cell-division this process of segregation is continued, so that the ids, as the phases of embryonic growth occur, contain more and more few different kinds of determinants. Supposing the germplasm to be composed of a million determinants at one stage, in the next it would contain only half a million, and in the next, again, only a quarter-million. In this manner the architecture of the ids becomes simpler and simpler, reaching the simplest conceivable condition in the active cells of the adult body. In these the germplasm consists only of the kind of determinants peculiar to the cells in which they lie; and these determinants are broken up into biophores, or bearers of cell qualities.

'The disintegration of the germplasm,' says Weismann, " is a wonderfully complicated process ; it is a true "development," in which the idic stages

1 The Germplesm, pp. 68, 69. 
necessarily follow one another in a regular order, and thus the thousands and hundreds of thousands of hereditary parts are gradually formed, each in its right place, and each provided with the proper determinants. The construction of the whole body, as well as its differentiation into parts, its segmentation, and the formation of its organs, and even the size of these organs-determined by the number of cells composing them-depend upon this complicated disintegration of the determinants in the id of germplasm. The transmission of characters of the most general kind-that is to say, those which determine the structure of an animal as well as those characterising the class, order, family, and genus to which it belongs--are due exclusively to this process.'

This mechanism of differentiating division fails to explain the phenomena of reproduction and of regeneration. For these Weismann has the following ancillary suppositions:

The first is the already-described hypothesis of continuity of the germplasm. As the disintegration of the germplasm into determinants, occurring in the development of an egg into an organism, is a process which cannot be retraced, and, as the future reproductive cells of the organism must contain undisintegrated, perfect germplasm, it follows that the germplasm in the germ-cells of the child must have come directly from the original germplasm of the parent. During the development, as Weismann assumes, only a few of the ids, each of which contains all the necessary germs, break up by differentiating division 
into the determinants which control the course of the ontogeny, and decide the final characters of the cells. Another set of ids remains undisintegrated, with their determinants fast bound together, and, in the cell divisions, is not broken up into dissimilar groups. The first set of ids is the active, disintegrating germplasm; the second set is a passive, latent germplasm, which may be described as accessory germplasm (Nebenkeimplasma). The active ids are his explanation of the embryonic events, which they direct; the accessory germplasm is reserved to form the germ-cells, and, in fast-bound condition, is handed on through a short or long series of cell-divisions alongside the active germplasm. Handed on in this passive state, it finally reaches a group of cells which may be many or few generations distant from the original eggcell, and impresses upon them the character of sexual cells. This transfer of germplasm from the egg to the sexual cell occurs in orderly fashion, along prescribed series of cells which Weismann has called the germ-tracks. Only these cells, which contain part of the perfect, undisintegrated germplasm, serve for the preservation of the species and are immortal ; the other cells, since, from the disintegration due to differentiating division, they contain only fragments of the perfect plasm (groups of determinants or single determinants), are mortal, somatic cells.

The formation of buds is explained in much the same way as the origin of germ-cells. There is handed along from the egg, through prescribed 
series of cells, a quantity of accessory, or bud, idioplasm.

The phenomena of alternation of generations require the supposition that in those animals and plants in which it occurs 'two kinds of germplasm exist, both of which always are present in the egg or in the bud, but of which one only is active at any time and rules the ontogeny, while the other remains inactive.' The alternating activity of these two produces the alternation of generations. So also dimorphism, which is exhibited most frequently as differences between the sexes, is explained by the assumption that 'double determinants' are present in the germplasm for all the cells, cellgroups, or entire organisms which have different characters in the male and female. One set of these double determinants remains latent, the other becomes active.

Finally, to explain the phenomena of regeneration, it is assumed that in the complicated cases where large parts of the body, like the head, the tail, or a bone, can be replaced after accidental loss, the cells with this power of regeneration contain, in addition to the determinants proper to them, supplementary determinants, which contain the germs needed for regeneration of the lost parts. These were handed on, during the ontogeny, through definite series of cells, in a passive condition, to become active when the conditions for their growth are supplied by the loss of the parts they can replace. 


\section{Criticism of the Germplasm Theory. ${ }^{1}$}

At first sight, much of Weismann's fabric of hypotheses gives the impression of being a closed system, thought out as a whole, and it has been treated as such in most of the notices and criticisms which I have seen. As a matter of fact, Weismann has spared no pains in the elaboration of his system, and has attempted to bring under his theory the many different phenomena of heredity and development, as well as alternation of generations, regeneration, atavism, and so forth. But, on the other hand, he has been careless in testing the stability and security of the foundations upon which he has built. It is on solid foundations that lie deep in the earth, and that avoid all reproach of being scamped or superficial work, that the durability of a structure depends. In this criticism the details of the superstructure will be disregarded, but the foundation will be tested thoroughly.

Cells and cell-properties are essential parts of Weismann's theory; while Naegeli has attempted to make his theory of the idioplasm independent of the whole conception of cells. In this matter I agree with Weismann, as, indeed, with De Vries and others, and I consider that the course taken by Naegeli has made his position untenable.

Naegeli would make his theory of the idioplasm

1 The following treatises contain criticisms of Weismann's theories: W. Haacke, Gestaltung und Vererbung; Leipzig, 1893; Herbert Spencer, articles in Contemporary Review (1893-94); Romanes, An Examination of Weismannism; Longmans, 1893. 
quite independent of the theory of cells, because, while cells are important units in morphological structure, independently of this they cannot be regarded as important units. 'By a unit,' he insists, 'we must understand, in a physical sense, a system of material particles. In the organic world there are very many kinds of higher and lower units; vegetable and animal individuals, organs, tissues, groups of cells (in the regetable kingdom, for instance, vessels and sieve-tubes), cells, parts of cells (plant cell-membranes, plasma, granules, and crystalloids, starch-grains, fatglobules, and so forth), micellæ, molecules, atoms. In morphology and physiology, sometimes one kind of unit, sometimes another, comes characteristically and notably into evidence. That being so, there is no reason why a special kind of unit should be exalted in a general theory.'

Athough, with Naegeli, we must recognise and keep in view the presence of a large number of higher and lower units in the organic world, a fact upon which I shall lay considerable emphasis later, we must none the less recognise that, among all elementary units, cells are most the conspicuous, morphologically and physiologically, in the whole organic realm. In actual research this is avowed very practically, as a glance at the biological literature of the last thirty years will show. Especially in the study of heredity, the cell is a unit that cannot be neglected, for it has been established that spores, ova, and spermatozoa, the units by which species are preserved in reproduction, both in the 
animal and in the vegetable kingdom, have the morphological value of cells.

In this point I am in opposition to Naegeli, although otherwise I agree with much in his conceptions.

A theory of heredity must be reconciled with the cell theory. In investigating Darwin's pangenesis, Galton's doctrine of the stirp, Naegeli's idioplasm, Weismann's germplasm, the intracellular pangenesis of De Tries, His' doctrinal of germinal foci for the formation of organs, or Roux's mosaic theory, I believe that one must face the question: How far do these doctrines agree with what we know about the structure and function of the cell? Moreover, in deciding between the alternativespreformation and epigenesis-I believe that it will profit us to start our critical investigation with the cell itself. With this object, I shall now sum up in a few sentences as much of our present knowledge of the life of cells as, I believe, must be reckoned with in any theory of propagation.

The cell, which consists of protoplasm and a nucleus, is an elementary organism, that, by itself, or in combination with other cells, forms the basis of all animal and vegetable organisation. In minute structure it is so extraordinarily complicated that its essential constitution (its micellar or molecular structure) eludes our observation. It is a medley, composed of numerous, chemically distinct particles that may be divided into two groups, organised and unorganised. The latter are free, or in solution; they are such as albuminates, fats, 
$\checkmark$ carbo - hydrates, water, salts, and they serve as material for the nutrition and growth of the cell. The former make up the living cell body (in the narrow sense). They are able to multiply by growth and division, and they are therefore the elementary parts, units of life of lower rank, of which the cell, a unit of higher rank, is composed. They are the gemmules of Darwin, the physiological units of Spencer, the bioblasts of Altmann, the pangenes of De Vries, the plasomes of Wiesner, the idioblasts of Hertwig, and the biophores of Weismann.

The cells of every organic species possess a proper, specific organisation, more or less complicated, and, in correspondence with this, they are composed of more or less numerous and varied organised particles.

The nucleus is a special organ of cells, which is always present. It displays a collection of numerous, peculiar, elementary living units, the idioblasts. These show chemical, morphological, and functional differences from the plasomes, the living units of the protoplasm; but perhaps the idioblasts, by absorption of different material, may transform themselves into the plasomes, just as these last, by a $\triangleleft$ similar process, may produce the plasma-products. In my view, the nucleus is the bearer of the idioplasm or hereditary material, that is to say, of a substance that is more stable than protoplasm, and, because it is less subject to influences of the outer world, it stamps its specific character upon the organism. ${ }^{1}$

1 Notwithstanding the objections raised by Bergh, Verworn, and Haacke, I abide by the supposition that the nucleus of repro- 


\section{A mass of protoplasm with several nuclei (like} the myxomycetes, cœloblasts, etc.) has the morphological value of a number of cells (synergides), corresponding to the number of the nuclei.

The means by which the continuity of life is maintained is the capacity of the cell to manifold itself by division, so forming two or more separate pieces. The process, which in most cases is associated with complicated changes of the nuclear contents, appears essentially to consist of the following : The elementary units of the cell (centrosomes, chromatin bodies in the case of nuclear division), being endowed with special energy resulting from the processes of growth, divide, and the elementary products of division separate into two groups, which move from the middle line;

ductive cells contains the hereditary mass or germinal material. My reasons may be found in my text-book on The Cell (English edit., p. 274). Briefly they are: 1 . The equivalence of the male and female hereditary masses. 2. The equal distribution of the growing nuclear mass of the primary egg-cell amoug the daughtercells that, arising from it, build up the organism. 3. The preservation of a constancy of bulk of the hereditary mass when fertilization occurs. 4. The isotropism of protoplasm. Following Pfligger, I mean by isotropism that the protoplasm of the egg does not contain local areas for the formation of different organs; but that, according to the conditions, any part of the protoplasm may be employed in the formation of any organ. Isotropism is merely the negation of His' doctrine of the presence of local areas for definite organs, and without losing its meaning, is compatible with the fact that many eggs have their poles different, and that others have a bilateral symmetry which determines the plane of the first division. 5. The fact that the first stages of many enbryonic developments consist in the multiplication of the nuclear material and its distribution in the yolk, following which the yolk-mass cleaves into cells. 
upon this there follows a division of the general body of the cell, i.e., of the protoplasm and its contents.

From the point of view of cells, I believe myself compelled to raise several objections to most important bases of Weismann's germplasm theory. For convenience of exposition these may be divided into two groups: Objections to the hypothesis of differentiating division; objections to Weismann's doctrine of determinants.

\section{Objections to the Hypothesis of Differ- entiating Division.}

A corner-stone of Weismann's theory is his assumption of nuclear divisions which are differentiating. Proof of this fundamental assumption may be sought in vain in Weismann's writings. Instead of that, a series of abstract arguments are brought forward in favour of it. Thus on p. 31 (of the English translation) Weismann treats the chromatin in the nucleus of the fertilised egg as the substance which accomplishes inheritance, and he denotes all the nuclei of the organism arising from the nucleus of the egg by divisions as the chromatin-tree, and then goes on to ask whether or no the pieces of hereditary material that make up the chromatin-tree of an organism are like each other or different. 'It can easily be shown,' the answer runs, 'that the latter must be the case.' For 'the chromatin is in a condition to impress the specific character on the cell in the 
nucleus of which it is contained. As the thousands of cells which constitute an organism possess very different properties, the chromatin which controls them cannot be uniform; it must be different in each kind of cell.'

Moreover, on p. 45 (of the English edition), "The fact itself' (the capacity on the part of the idioplasm for regular and spontaneous change) 'is beyond doubt. When once it is established that the morphoplasm of each cell is controlled, and its character decided, by the idioplasm of the nucleus, the regular changes occurring in the egg-cell, and the products of its division in each embryogeny, must then be referred to the corresponding changes of the idioplasm.'

Finally, on p. 205 (of the English edition), "The cells of the segmenting ovum are completely dissimilar as regards their hereditary value, although they are all young and embryonic, and are not infrequently quite similar in appearance. It therefore seems to me to follow from this, as a logical necessity, that the hereditary substance of the eggcell, which contains all the hereditary tendencies of the species, does not transmit them in toto to the segmentation cells, but separates them into various combinations, and transmits them in groups to the cells. I have taken account of these facts in considering the regular distribution of the determinants of the germplasm, and the conversion of the latter into the idioplasm of the cells in the different stages of ontogeny.'

In the different propositions I have quoted, we 
have to deal with what is merely a fallacy in rhetorical disguise. For, from the premiss that the chromatin has the power of impressing specific character upon the protoplasm of the cell, it by no means follows that two cells, distinguishable by the nature of their plasma-products, must therefore contain different kinds of protoplasm. There are other possibilities to be reckoned with. Weismann himself knows that there is no logical necessity for the conclusion, for he himself suggests another possibility in the following: "If we wished to assume that the whole of the determinants of the germplasm are supplied to all the cells of the entogeny, we should have to suppose that differentiation of the body is due to all the determinants except one particular one remaining dorrnant in a regular order, and that, apart from special adaptations, only one determinant reaches the cell, viz., that which has to control it. If, however, we do make the assumption,' etc. (p. 63, English edition).

Here, then, Weismann himself points out that what in other places he has attempted to represent as a necessary conclusion is but one of two alternatives.

Not only does he grant the possibility of the alternative, but uses it himself in explanation of the phenomena of reproduction and development. He attributes to certain series of cells, in addition to the active rudiments controlling the normal characters of their protoplasm, the possession of numerous latent rudiments which become active when opportunity presents itself. 
This non sequitur in his argument Weismann excuses with the remark that the presence of latent rudiments in special cases 'depends, as I believe, upon special adaptations, and is not primitive, at any rate not in higher animals and plants. Why should Nature, who always manages with economy, indulge in the luxury of always providing all the cells of the body with the whole of the determinants of the germplasm, if a single kind of them is sufficient? Such an arrangement will presumably have occurred only in cases where it serves definite purposes ' (p. 63, English edition). Here, again, is a rhetorical flourish instead of a proof.

But the dilemma which we are examining is not yet at an end. Supposing for the moment that we accept the assumption that different character in cells implies different character in their nuclear matter, we have at once a new and important decision to make. Does the nuclear matter in the different cells, that has arisen by division from the nuclear matter of the egg-cell, become unlike by the process of division itself? or is it only after the division that it becomes different, and in consequence of the action of outer forces upon the nuclei?

Weismann decides boldly-but again without bringing forward proof-in favour of the former interpretation. 'For the chromatin,' he remarks, ${ }^{1}$ 'cannot become different in the cells of the fully formed organism; the differences in the chromatin controlling the cells must begin with the develop-

${ }^{1}$ English edition, p. 32. 
ment of the egg-cell and must increase as development proceeds; for otherwise the different products of the division of the egg-cell could not give rise to entirely different hereditary tendencies. This is, however, the case.' Weismann represents to himself that ' the changes of the idioplasm depend on purely internal causes, which lie in the physical nature of the idioplasm. In obedience to these, a division of the nucleus accompanies each qualitative change in the idioplasm, in which process the different qualities are distributed between the two resulting halves of the chromatin rods.'

I shall proceed to show that this conception involves material difficulties and contradictions. It will be found that characters totally contradictory are ascribed to Weismann's idioplasm. On the one hand, it is credited with being a stable substance, possessing a coherent, complicated architecture ; in the form of ancestral plasms it is supposed to be handed on, from one individual to another, unchanged through many generations; on the other hand there is ascribed to it a labile architecture, that allows a free and perpetual casting loose of rudiments, of such a kind that at each division there is caused a complete rearrangement and unequal division of these rudiments. In the one case, the inner forces produce a reciprocal, coherent bond between the numerous rudiments; in the other case, permit change of their position and relations to one another, and this not only once but in orderly', definite fashion, different in each of many 
successive divisions, so that the id comes to possess a completely altered architecture. 'Each $i d$ in every stage' (p. 77 of the English edition), ' has its definitely inherited architecture; its structure is a complex, but a perfectly definite one, which, originating in the $i d$ of germplasm, is transferred by regular changes to the subsequent idic stages. The structure exhibited in all these stages exists potentially in the architecture of the $i d$ of germplasm: to this architecture is due, not only the regular distribution of the determinants-that is to say the entire construction of the body from its primary form.'

Unfortunately, Weismann's hypothesis tells us nothing at all about these internal causes, that depend upon the physical nature of the idioplasm; that is to say, nothing at all about the causes which, working in a fashion so contradictory and astonishing, really produce the whole development.

In such a state of affairs it is better to turn to Nature herself, and to see whether or no the occurrence of differentiating division of the nucleus in the organic world is at all supported by the actual observations and investigations of those who study cells.

We shall examine (1) Unicellular organisms; (2) Lower multicellular organisms; (3) The phenomena of generation and regeneration; (4) alteration of structural growth due to external interferences (heteromorphosis); (5) A number of physiological indications that cells and tissues, in 
addition to their patent characters, contain latent characters which have reached them by doubling division, and which are representative of the species.

FIRST GROUP OF FACTS.-UNICELLULAR ORGANISMS.

Doubling division alone exists, or could exist, among unicellular organisms. The maintenance of the species depends upon this. Our belief that a species produces only its own species, that like begets only like, a belief that finds continual confirmation all through the study of systematic and embryological natural history, would disappear, were it possible that in the division of unicellular organisms the hereditary mass should be split into two unequal components and be bestowed unequally upon the daughter-cells. All research shows that unicellular fungi, algæ, infusoria, and so forth, in dividing, transmit specific characters so strongly and in detail so minute that their descendants, a million generations off, resemble them in every respect. No one has doubted the fact, and Weismann himself recognises that division, among unicellular organisms, is always doubling. The process of division, as such, appears never to be the means by which new species are called into existence among unicellular organisms. This is a fundamental proposition of cell-life, not to be doubted, and to be taken into account in the presentation of theories of heredity.

From the proposition that like begets only like 
the corollary by no means follows that mother- and daughter-cells must appear identical from the beginning. For the identity under consideration belongs only to the substance that is the bearer of specific characters, to the hereditary mass ; besides that, a unicellular organism contains other substances, substances that change from time to time during its life. Many unicellular organisms pass through a regular series of developmental stages; the stages themselves being inherited, and following each other as infallibly as in the case of embryonic stages of higher animals.

The following will serve as examples of this. Podophrya gemmipara, an Acinetan, in the adult condition is attached by a long stalk, while the free end, at which is the mouth, is provided with suctorial tentacles. It reproduces by giving rise to many little buds, ciliated on the upper surface like free-swimming, hypotrichous infusoria. These, in appearance, are quite unlike the parent organism, and, after a vagrant existence in the water for some time, they attach themselves to a surface and produce a stalk, tentacles with suctorial pseudopodia, and so for the first time attain the maternal form.

Some Gregarines are İarge, jointed cells, divided into two pieces, a protomerite and a deutomerite; they are clad with a cuticle, under which lies a layer of muscular fibrils. After conjugation they encyst, the nucleus divides, and they break up into numerous peculiarly-shaped boat-like structures, (pseudonavicellæ), which afterwards are set free as small, sickle-shaped embryos. These exceedingly 
small germ-cells afterwards develop into the very different, adult gregarine-cells.

If the characters of a species be associated with a hereditary mass, an actual substance that is handed on from the parent-cell to the offspring, it is clear that the infusoria-like vagrant young of the Acinetan, and the sickle-shaped embryos of the Gregarine possess it, although for some time they are quite unlike the parent organism. For at last they become an Acinetan or a Gregarine, exactly like the parent-cell from which they arose as embryos.

These circumstances, among unicellular organisms, are a weighty indication of the error of concluding, with Weismann, in the case of multicellular forms, that because cells are unlike in outward appearance, the hereditary mass, or, as I call it, the nuclear matter, within them is also unlike. Such an assumption would involve us in the greatest contradictions. For the supposition that the nucleus is the hereditary mass transmitting the characters of the species necessitates the conclusion, in the case of unicellular forms, that the hereditary mass remains in possession of all the rudiments of the cell while it passes through the various phases of its cycle of development. Otherwise, these phases would have to be acquired anew in each case. We must, therefore, represent the possibilities of exchange between the nucleus, in its capacity of hearer of the hereditary mass, and the protoplasm as being such that all the rudiments are not simultaneously in activity, but that some of them can remain latent for a time. 
SECOND GROUP OF FACTS.-THE LOWER MULTICEILULAR ORGANISHS.

Although in the development of unicellular organisms the way by which like begets like is plain and intelligible enough, at least in the cases dealt with, it is different with multicellular organisms, which have reached a higher grade of development. Among them we have to do with a continuous process of development, in which the highlydifferentiated, multicellular organism arises from an egg, and in turn gives rise to an ego, and so on in unending sequence. But the succeeding stages of the sequence are so exceedingly dissimilar in appearance that the question how one step of the series turns into the next, and, above all, the question how the similarity of organisms, separated by the egostage, can be transmitted through the egg-stage, form the deepest riddle offered to biological investigation. Here, in a completeness so wonderful that our intelligence can hardly apprehend it, are presented to us the qualities of the organic material of which cells are made. Here lies that dark secret into which the various theories of generation try to direct a beam of light, and seek to find out the direction in which explanation may be found.

An intermediate stage which may serve towards the explanation of these circumstances is presented by the lower multicellular organisms, such as threadlike algæ, fungi, and other simple creatures. In them cells arise by division from the egg or from the spore, and become united into an in- 
dividual of a higher rank; these cells resemble one another so completely in appearance and in qualities that there can be as little doubt as in the case of unicellular organisms that they arose by doubling division.

It is certain, then, that there exist multicellular bodies, often consisting of many thousand cells, in which each part retains the qualities of the egg from which it arose by doubling division, and which, as that method implies, possess the rudiments of the whole of which each is a part.

In this category there naturally fall the multinucleated masses of protoplasm, sometimes highly organised, in which every nucleus, surrounded by a shell of protoplasm, is capable of reproducing the whole. I am thinking of the slime-fungi (Myxomycetes), with their peculiar formation of reproductive bodies; of the 'acellular plants,' which in some cases closely resemble multicellular species in their formation of leaf and root, and in their mode of growth, as, for instance, Caulerpa, the multinucleated Framinifera and Radiolarians. For, according to our definition of the cell, a multinucleated organism potentially is a multicellular organism.

In this matter Weismann has assumed a position which leads to peculiar consequences. In his opinion, somatic cells and germ-cells were sharply distinct at their first appearance in evolution, and have remained so ever since. 'Transitional forms between them are nowhere to be found. It would be inconsistent with his theory of the germplasm had somatic cells contained germplasm as their 
idioplasm, even when the soma first came into existence. The phyletic origin of the somatic cells depended directly upon an unequal separation of the determinants contained in the germplasm. It would totally contradict his presentation if the somatic cells, even at their first origin in phylogeny, contained, in addition to their patent special qualities, the qualities common to the whole species in a latent condition.

Weismann's conception, therefore, implies that many of the lower multicellular organisms, having: no somatic-cells, have no body. Take the closelyallied creatures Pandorince morum and Volvox globator, which Weismann himself brings forward as instances for his view; the latter has a body, the former has no body, as all its cells are able to serve for reproduction!

It is enough to have pointed out how contradictory are the interpretations in this matter. Enlarging upon them may be postponed at present, for we are concerned here not with the interpretation of individual cases, but with the principles involved in the question, and, therefore, we must pass on to show further reason for considering the existence of differentiating division highly improbable in the whole organic world.

THIRD GROUP OF FACTS. - THE PHENOMENA OF REPRODUCTION AND REGENERATION IN PLANTS AND ANIMALS.

The numerous phenomena of reproduction and regeneration appear to support the principle of 
doubling division-that is, of division in which the germinal substance is handed on to every part of the organism. Our review may be short, as the phenomena are matters of common knowledge.

In nearly all plants there exist, widely spread through the body, cells and cell-groups, which may be induced, by inner or outer influences, to give rise to a bud; the bud grows out into a shoot, ultimately producing flowers and genital products. Such happens both in parts of the plant above the ground and below it; in the latter case shoots arise from roots, and reproduce the species in the ordinary sexual fashion by bearing sexual products.

Thus, in the case of Funaria hygrometrica, a little moss, one may chop up the plant into tiny fragments, scatter these on damp earth, and see numerous moss-plants reproduced from the little groups of cells. By cutting little pieces from a willow, an experimenter may cause the production from slips of thousands of willow-trees, each with all the characters of the species, so that there must have been contained in each of the little pieces of tissue hereditary masses with the characters of the whole plant. Separate pieces of the leaves of many plants, as of the begonia, produce buds from which the whole plant may grow out.

An aptitude for reproduction like that in plants exists in many cœlenterates, worms, and tunicates. The polyps of hydroids and of bryozoa, the stolons of an ascidian (Clavellina lepadiformis), may give rise to buds in many places, and these grow up into the perfect hydroid, bryozoon, or ascidian. 
There must, then, be contained in the cells of the bud the germinal rudiments of the whole animal; this conclusion is more necessary as the individuals, produced from the buds, in due course bear sexual products.

Although in many higher animals and plants one sees that cells with the capacity for reproduction are limited to special areas, still, the capacity for regeneration often is very great. In a wonderful fashion animals will reproduce lost parts, sometimes of most complicated structure; just as a crystal, from which a corner has been chipped, will perfect itself again when brought into a solution of its own salt. A Hydra, from which the oral disc and tentacles have been cut off, a Nais deprived of its head or of its tail, a snail of which a tentacle with its terminal eye has been amputated, will reproduce the lost parts, sometimes in a very short time. The cells lying at the wounded spot begin to bud, producing a layer or lump, the cells of which resemble embryonic cells. From this embryonic mass of cells the lost organs and tissues arise-in Hydra, the oral disc with its tentacles; in Nais, the anterior end with its sense-organs and special groups of muscles; in the snail, the tentacle with its compound eye built up of elements so different as retinal-rods, pigment-cells, nerve-cells, lens, and so forth.

Even among vertebrates, in which the capacity for regeneration is the least, as in the restoration of the wounded parts small defects occur, lizards can reproduce a lost tail, tritons an amputated 
limb. From a bud of embryonic tissue there are elaborated in the one case whole vertebræ, with their muscles and tendons, and part of the spinal cord with its ganglia and nerves, in the other case, the numerous, differently-shaped, skeletal pieces of the hand or foot, with their appropriate muscles and nerves. The regeneration, moreover, is in strict conformity with the characters of the species concerned. Thus, from the facts of regeneration also, we must infer that cells in the vicinity of these casual wounds possess not only the special qualities which they possess as definite parts of a definite whole, but also the characters of the whole, and thus have the power of becoming buds, from which a complicated part of the body may be reproduced with the appropriate characters of the species.

\section{FOURTH GROUP OF FACTS.-THE PHENOMENA OF} HETEROMORPHOSIS. ${ }^{1}$

Of all the facts brought forward here, the phenomena of heteromorphosis perhaps bear most strongly in favour of my conception, and offer

${ }^{1}$ In this section upon heteromorphosis I rely upon the following treatises, which have appeared recently. Loeb, Untersuchungen zur physiologischen Morphologie der Thiere. Organ-bildung und Wachsthum. Heft, 1 and 2 (1891-1892). H. de Vries, Intraeellulare Pangenesis (1889). H. Driesch, Entwicklungsmeehanische Studien, i.-vi. ; Zeitschrift f. wissenschaft, Zool., vol. liii.-lv. The same, Zur Theorie der thierischen Formbildung. Biol. Centralblatt, vol. xiii., 1893. Chabry, Contribution à l'embryologie normale et tératologique des Ascidies simples. Jour. de l'Anat. et de Physiol. (1887). Wilson, Amphioxus and the Mosaic Theory. Journal of Morph. (1893). See also Anatomischer Anzeiger (1892). 
difficulties most irreconcilable with Weismann's theory.

Loeb uses the word ' heteromorphosis' to denote the ability possessed by organisms, under the stimulus of external forces, to produce organs on parts of the organism where such do not occur normally, or the power to replace lost parts by parts unsimilar to them in form and functionRegeneration is the reproduction of parts like those lost; heteromorphosis is the reproduction of parts unlike those lost.

Heteromorphoses are well known in plant physiology. When one cuts a slip from a willow, one may make the cut at the bottom of the slip and the cut at the top in any part of the willow-twig, yet still the lower end of the slip always produces rootlets, which are organs not normal to that part of the twig, while shoots will rise from the upper end. Moreover, either end of the slip may be made the root portion, and it is clear, therefore, that in every small area there are cell-groups present able to bear roots or shoots according to the determining conditions; and therefore that, in addition to the characters active at any time, there are present the germinal rudiments for shoots and roots, and, indeed, for the whole organism, since the shoots ultimately may bear genital products.

When the prothallus of a fern has developed normally, it is a flattened leaf-like structure which bears rootlets and male and female genital organs on the lower surface, i.e., on that turned from the light. But the experimenter may reverse this 
order, by artificially shading the upper surface, and strongly illuminating the lower surface.

Among the most interesting heteromorphoses are the galls, produced upon young plants when certain insects lay eggrs on them, or when plant-lice irritate their tissues. From these abnormal stimuli there result active masses of cells which grow into organs of definite form and of complex structure. The galls, moreover, differ widely, in correspondence with the specific stimulus which was their initial cause, and with the specific substance, the stimulation of which resulted in the formation of a gall. By the action of different insects upon the same plant different galls are produced, and the galls of different plants may be distinguished systematically.

Blumenbach has already brought forward the existence of galls as an argument against preformation, holding them to be structures produced epigenetically, and, therefore, unrepresented by rudiments in the germ. I, also, consider them witnesses against Weismann's germplasm. They teach us that the cells of the plant-body may serve purposes quite different from those arranged for in the course of development; that cells modify their form in correspondence with novel conditions, and that they are forced into forming special structures, not by special determinants in the germ, but by external stimulants.

Galls exhibit yet another instructive kind of heteromorphosis.

Even the tissue of a leaf, turned into a gall by 
pathological conditions, retains the power of producing roots. Beyerinck has shown that galls of Salix purpurea, planted in moist earth, bear rootlets identical with those of the normal plant. As the roots of all woody plants are able to bear adventitious buds, De Vries thinks it probable that one could rear a whole willow-tree from a gall. That would imply that all the inheritable characters of the willow were contained even in the gall.

Loeb has produced heteromorphoses experimentally upon many lower animals, among which were Tubularia, Cerianthus, and Cione intestinalis.

In Tubularia mesembryanthemum, a hydroid polyp, there are stalk, root, and polyp-head. If one cut off the head, a new head will be formed in a few days, this being a case of regeneration. On the other hand, a heteromorphosis may be produced by modifying the experiment as follows: Both root and head must be cut from the stem; if the lopped piece of the stem be stuck in the sand of the aquarium by the end that bore the head, then the original aboral pole in a few days produces a head; if the lopped piece of stem be supported horizontally in the water, then each end of it produces a head.

In a Cerianthus membranaceus (Fig. 1), the body was opened by a cut some distance below the mouth, whereupon buds appeared on the lower edge of the slit, where the experimenter had prevented coalescent growth. These buds gave rise to inner and outer tentacles, and an oral disc was 
produced. Thus, artificially, an animal with two mouth-openings or two heads was produced; and,



Fig. 1.-Cerianthus membranaceus, in which a second oral aperture, surrounded by tentacles, has appeared as the result of an artificial slit. (After Locb.)

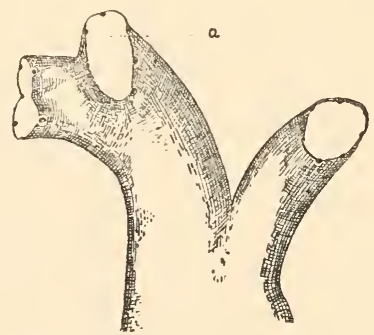

Fig. 2.-Cione intestinalis, in which eye-specks resembling those surromding the month have appeared in the neighbourhood of an artificial opening $(a)$.

similarly, animals with a row of three or more heads may be produced. 
The third animal in which heteromorphosis was produced artificially was Cione intestinalis, a solitary ascidian, an animal more highly organized. In Cione (Fig. 2) the edges of the mouth-opening and of the cloaca are provided with numerous, simple eye-spots. Loeb, in a series of experiments, made incisions either into the inhalent or the exhalent tube ; after a time eye-spots appeared round the edges of the cut; then the margin of the artificial oral opening grew out into a tube, even longer than the normal oral tube. "If several incisions be made simultaneously at different places on the same animal, then several new tubes arise simultaneously.'

In the three cases, the cut surfaces, from which in Tubularia, a head, in Cerianthus, tentacles, and in Cione, eyespots, took their origin, were made in different parts of the bodies and in different directions. Thus, again, we have an indication that there are present in most regions of the body cellgroups, which may give rise to complex organs in unnatural positions, and yet bearing the specitic stamp.

These examples might easily be multiplied, and they serve to show that heteromorphosis in plants and animals implies the presence of numerous latent characters in cells and tissues, in addition to the characters proper to their normal position in the organism. These latent characters, under the impulse of stimulation from without, manifest themselves in abnormal formation of organs in abnormal situations. Save that they are in ab- 
normal situation, the induced organs conform to the specific type in all respects, and indicate that all the cells of an organism contain, as the result of doubling division, the characters of germinal rudiments of the whole organism. On the other hand, heteromorphoses bear heavily against the doctrine of determinants. For it is impossible that, in the architecture of the germplasm, there can be provision, in the form of special determinants, for events so foreign to the natural course of derelopment as these arbitrary, outer stimulants.

Heteromorphosis may be extended to include more than Loeb intended by reckoning under it artificially-produced modification of the early stages in the cleavage of the egg. I have in mind those experiments by Driesch, Wilson, and myself, in which the first cells of the embryonic history were induced to form parts of the embryo, to which in the normal course they would not have given rise. In these cases heteromorphosis begins from the first cleavage of the egg.

In an ingenious way Driesch compressed fertilised echinoderm eggs between glass plates, and so secured that the first sixteen cells were separated, not by alternate vertical and horizontal planes, as in the normal development, but only by vertical planes. In the resulting one-layered plate of cells the nuclei had relative positions quite different from the normal. As, notwithstanding this, the distorted eggs developed into normal plutei larvæ, Driesch inferred that the cell material composing the earliest cells of echinoids is equivalent in all 
the cells, and that the cells may be pushed over one another like a heap of balls without disturbing in the slightest their capacity to develop. Such a permutation could be without injury to the developmental product only if one nucleus had the same qualities as another; that is to say, only if all the nuclei had arisen from the nucleus of the fertilized egg by doubling division.

Driesch is right to regard these experiments as incompatible with Weismann's theory. 'Only consider,' he remarks, 'how great a number of "supplemental hypotheses," how many "accessory determinants," would be required to make specification of the early stages of a development in which any nucleus may take the place of any other nucleus in the whole embryo.'

I myself have carried out similar experiments upon frogs' eggs-experiments with a double interest. The frog's egg has the poles different, and so has a definite orientation. Weismann and Roux themselves have used these objects to support their view that, at the first cleavage, nuclei with different qualities are formed.

On p. 64 of the English edition Weismann remarks: "The fact that the right and left halves of the body can vary independently in bilaterally symmetrical animals points to the conclusion that all the determinants are present in pairs in the germplasm. As, moreover, in many of these animals-e.g., in the frog-the division of the ovum into the two first embryonic cells indicates a separation of the body into right and left halves, 
it follows that the $i d$ of germplasm itself possesses a bilateral structure, and that it also divides so as to give rise to the determinants of the right and left halves of the body. This illustration may be taken as a further proof of our view of the constant architecture of the germplasm.'

Roux ${ }^{1}$ has based his mosaic theory upon experiments upon frogs' eggs. According to the theory, the first two segmentation spheres contain not only all the formative material for the right and left halves of the embryo respectively, but also the differentiating and elaborating forces for these, so that on the destruction of one cell, the other can give rise only to one lateral half of the embryo (hemiembryo lateralis). Roux, therefore, consider's that by the first cleavage the nuclear material is

${ }^{1}$ Roux tried to give experimental evidence in favour of his mosaic theory in a treatise On the Artificial Productions of HalfEmbryos by the Destruction of one of the first two Cleavage-Cells, and on the Reconstruction of the Lost Parts. Virehow's Archiv., vol. exiv., 1888. Roux defends his mosaic theory against Driesch and myself in (1) Ueber das entwickhnngsmechanische Vermögen jeder der beiden ersten Furchungszellen des Eies. Verhandl. der Anat. Gesellsch. der 6ten Versamml. in Wien, 1892. (2) Ueber Moscikarbeit und neuere Entwicklungshypothesen. Anatomische Hefte von Merkel und Bonnet (1893). Also in Biol. Centralblatt (1893); in the Anatom. Anzeiger (1893), and in the treatise Die Methoden zur Erzcugung halber Froschembryonen und sum Nachneis der Bezichung der ersten Furchungsebenen des Froscheies zur Hedianebene des Embryo. Anatom. Anzeiger. (1894); Nos. 8 and 9.

If, as would appear from the last treatise, Roux would avoid being reckoned with evolutionists, he must abandon his mosaic theory, and this he has not done. I think in the present essay, on theoretical and experimental grounds I have shown the untenability of Roux's mosaic theory. 
broken up into unlike halves, by which the development of the corresponding cells is directed
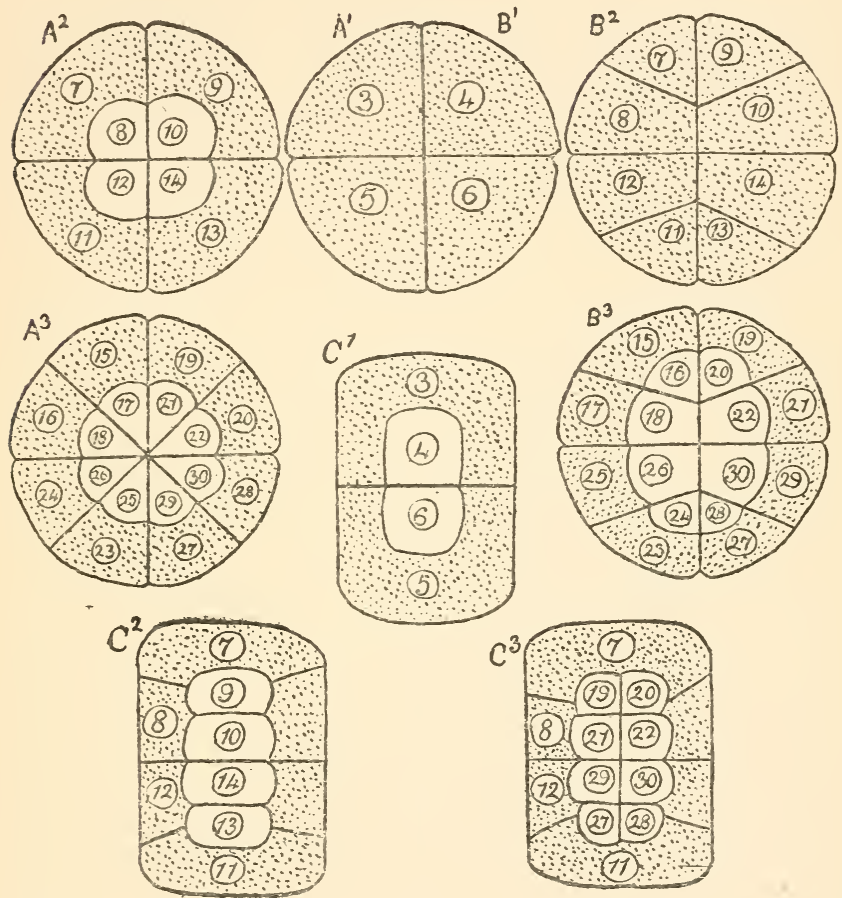

Fig. 3,-Difarams of the Egres of Frogs, which show how alteration of the cleavage process changes the morle in which the nuclear material is distributed. The nuclei indicated by the same numbers have the same descent in all the diagrams. All the eggs are viewed from the animal pole. A. Normally developing eggs. B. Eggs developing under compression by horizontal plates. C. Eggs developing under compression by vertical plates.

diversely, i.e., is determined in a specific fashion. The error in these representations of Weismann 
and of Roux has been shown by varied experiments of my own. The eggs of frogs on the point of cleaving were flattened to a disc between vertically or horizontally placed glass-plates. In the first case they were flattened in the dorsoventral direction, i.e., the axis passing through the animal and vegetative pole was shortened; in the second case an axis at right angles to this was shortened. In both cases the course of cleavage, and the resulting distribution of the nuclei in the yolk, was artificially modified.

The diagrams A, B, C (Fig. 3) will make the results plain to the reader. A, represents the distribution of the nuclei after normal cleavage; $B$, the same, when the egg was pressed between horizontally-arranged parallel glass-plates; C, the same, where the flattening was produced by vertically-placed parallel glass-plates. ${ }^{1}$

The diagrams show the positions of the segmentation spheres and of the contained nuclei as seen from the animal pole. In stages where two layers of cells as a result of division lay one above the other, the cells of the lower layer are distinguished in the figure by shading. In the three diagrams the nuclei are numbered so that the reader may know how far they are removed from the nuclei of the first two segmentation spheres. The numbers are further exhibited in the following two genealogical trees:

1 The terms vertical and horizontal refer to the vertical axis of the egg, which passes through the animal and vegetative poles.Translator's note. 



In the three diagrams the nuclei with the same numbers have the same rank in descent, and therefore, according to the theory of Roux and Weismann, have the same qualities, while the nuclei with unlike numbers differ in qualities.

Let us now notice how the nuclei in the three processes of division, of which two are abnormal, are placed in the mass of the egg.

After the first division, the nuclei are alike in all three cases; after the second difference appears. In $\mathrm{A} 1$ and $\mathrm{B} 1$ nuclei 3 and 5 lie to the left; 4 and 6 to the right of the second cleavage-plane, which, according to Roux's hypothesis, corresponds to the median-plane of the future embryo; while in $\mathrm{C}$ they are forced into two layers, one above the other, nuclei 4 and 6 being dorsal, 3 and 5 ventral.

In the third cycle of division there is no agreement between the three cases.

In the diagrams $\mathrm{A} 2$ and $\mathrm{B} 2$ the nuclei still lie similarly to the right and left of the middle line; but in A2 they are arranged in two layers, in B2 in a single layer. The nuclei $8,10,12$, and 14 , which compose the upper layer in A2, form the middle of the disc in B2; and 7 and 9, 11 and 13, the ventral nuclei of A2, occupy the ends of the single-layered dise of B2, being closely pressed against each othe:. 
In the diagram C2 there is actually no medianplane after the third cycle of division. The nuclei $9,10,14,13$, which in $\mathrm{A}$ and $\mathrm{B}$ form the right side of the mass, here form a dorsal layer with nuclei $7,8,12,11$, forming a ventral layer. In the fourth cycle of division the nuclear matter is still more variously distributed through the mass, as may be seen from comparison of diagrams A3, B3, C3.

Although, under normal conditions, the multiplication and division of the nuclear material occurs in an almost invariable and definite fashion, the mere altering of the spherical form to a cylinder or to a disc produces a method of division completely different, so far as the nuclei are related to each other in a genealogical tree. In the one and the other method of division the nuclei are brought into relation with different regions of the protoplasmic mass, and are united with these regions to form cellular individuals.

I had quite enough reason for what I said in my essay: 'If the doctrine of Roux and Weismann be true, and the successive divisions by which nuclei arise really place different qualities in the nucleiqualities according to which the masses of protoplasm surrounding them become different and definite parts of the embryo-what a pretty set of malformations must result from eggs in which the nuclear matter has been shufled about so wantonly! As such malformations do not occur, it is plain that the doctrine is untenable.'

We reach the same conclusion from consideration of the interesting experiments made by Driesch 
and Wilson upon the early stages of segmentation of the egg. In the cases of an echinoid and of amphioxus (Fig. 4) they succeeded in shaking apart the first two and the first four cells that arose in division of the egg; and they traced the subsequent development of these separated segmentation spheres.

From one of the first two segmentation spheres of an echinoid egg, Driesch was able to rear successive embryonic stages (Gostrulu and Pluteus), which were normal in shape, but one-half the usual size. Wilson's results, obtained by shaking apart

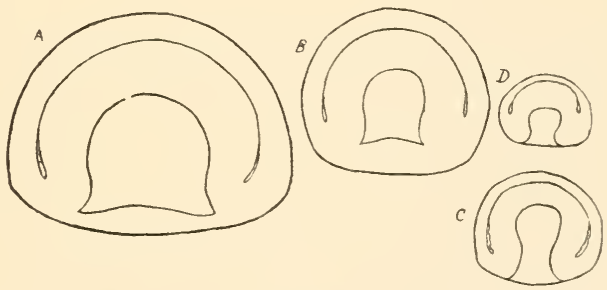

Fig. 4.-Normal axt Fractional Gastrula Amphioxls. (After Wilson.)

A Gastrula from a whole egg ; B, C and $\mathrm{D}$, gastrulie from single cells artificially separated, (B) from the two-celled stage, (c) from the four-celled, and (D) from the eight-celled stages of normal development.

the segmentation spheres, were even more interesting, as they were performed upon amphioxus, a more highly-organized animal. He reared gastrulæe and older embryos with notochord and nerve-tube, which were perfect and normal, except in size. They were one-half, one-quarter, or one-eighth of the usual size, according as they were reared from 
cells isolated from the two, four, or eight-celled stage of the segmenting egg.

Results which Chabry and I gained by destroying, by puncture, one of the first two segmentation spheres, assist the present argument. Although one-half of the mass had been destroyed, Chabry obtained, in the case of an ascidian, and I obtained, in the common frog, embryos with notochord and nerve-plate. These developed directly and normally, although, in the case of the frog, there was a slight defect at the ventral posterior part of the body, where the arrested protoplasmic mass came to lie.

All these experiments show that the first two (and in some cases the first four) results of division can assume a quite different bearing as regards their function in the mechanical building of the embryo, according to whether they remain bound with each other into a whole or are separated and develop by themselves. In the former case, each forms only one-half (in some cases only a fourth) of the whole. In the latter case, each by itself produces the whole. The half and the whole, then, of the first cleavage-cells are identical in real nature, and, according to the circumstances, can develop, now in this way, now in that.

Even if Weismann were to admit the correctness of these experiments, perhaps he would not consider that they contradicted his theory of the germplasm and the segregation of the hereditary mass, but would make a supplemental hypothesis, which, from the spirit of his theory, could be none other than this: each of the first cleavage-cells, in 
addition to its specific part of the hereditary mass, the part that controls its normal course of development, possesses an accessory idioplasm, an undivided fragment of the germplasm, left behind to be ready for unforeseen emergencies; this part takes command when, in consequence of violence, a separated part develops into the whole.

But such an assumption does not go far enough, if it be confined to the first cleavage-cells. By compression of the frog's egg, I have shown that the pole passing through the blastopore, which coincides with the chief axis of the future embryo, may assume different relations to the first segmentation-plane, sometimes coinciding with that, sometimes making a right or an acute angle with it. It is clear that in each of these cases the embryonalcells take a different share in the formation of the regions of the body, and that they must be foreendowed with the capacity of playing different parts.

The developmental history of double monsters enforces the same doctrine; such are common among the embryos of fish, and rather less common among chicks. From causes of which we are ignorant two, instead of one, gastrula stages may arise at separate regions of the germinal layer of the egg. According to the position of these two invaginations, which may be regarded as crystallisation-points for the formation of the future embryo, the cells of the germinal disc will be drawn into the process of development, and, falling into groups, will build up organs. In relation to this 
double gastrulation, there may arise, for instance, four instead of two primitive ears, eyes, and nasal organs; and these arise from cell-groups, the choice of which is determined by their relation to the position of the gastrula-invagination.

From various other experiments, conducted so as to distort the normal course of development, I have obtained parallel results.

Taking frogs' eggs immediately after fertilisation, I compressed them strongly between parallel, horizontally placed glass plates. I then inverted them, so that the vegetative pole came to lie uppermost. In spite of their unnatural relation to gravity, they developed further, and became abnormal, quite unsymmetrical embryos.

In another experiment, taking a triton's eggs after they had divided into two spheres, I surrounded them with a silk thread in the plane of the first cleavage, and tightened the thread until the embryo assumed the form of a sand-glass. The deformity of the resulting larvæ was very different, and perhaps depended on the tightness of the constriction. Some became greatly elongated, and had developed so that the thread surrounded the dorsal nerve-cord. In other cases the dorsallyplaced organs arose only from one-half of the sandglass-shaped embryo, while the other half gave rise to the ventral part of the body. In this case the dorsal organs (nerve-tube and notochord) were doubled over like a snare, the head and tail ends, the mouth and the region of the anus, being bent in at the position of the constricting thread. 
The important point is that in both the experiments, in the case of the frog and of the triton, the cell-material, separated at the first cleavage, was turned to a use quite different to its use in the formation of a normal embryo.

We may conclude with a very convincing proof. In the above-mentioned abnormal development of the frog's egg it happened that one edge of the blastopore, on account of its weight, was very much bent outwards. In consequence of this the cleft of the blastopore lay between the normal blastoporelip and the everted border of the other lip. When the notochord and the nerve-plate appeared, as a result of this abnormal condition, they grew from a cell-material that was quite different to that which gives them origin in normal cases. ${ }^{1}$

In these cases Weismann cannot apply his accessory conception, the existence of supplementary idioplasm, only to the nuclei arising from the first division; he must extend it to the thousands of embryonic cells that arise by division up to the time for the appearance of the nerve-tube and notochord. The behaviour of these cells under fortuitously changed conditions shows them all to be endowed with the capacity of development in different directions.

${ }^{1}$ Further details concerning these experiments may be found in HeRTwig, Ueber den Werth der ersten Furchungszellen für die Organbildung des Embryo. Experimentelle Studien am Froschund Tritonei. Archiv. für Mikrosk. Anatomie, vol. xlii., 1893, p. 710 ; Plate xli. ; Figs. 1, 2, 27. 


\section{FIFTH GROUP OF FACTS.-PHENOMENA OF VEGETATIVE AFFINITY. ${ }^{1}$}

Many considerations, taken from the region of general physiology, support the view that all the cells of an individual, of any species, are alike, and are to be distinguished from one another only by the special development of one character.

${ }^{1}$ For the facts in this section I rely in particular upon the writings of Vöchting, Bert, Ollier, Trembley, Landois, Ponfick, and others :

H. Vöchting: Ueber Transplantation anf Pflanzenkörper. Untersuchungen zur Physiologie und Pathologie; Tübingen, 1892.

Von GÄrTNER: Versuche und Beobachtungen ueber die Bastarderzengung im Pflanzenreich, 1849.

LÉOPOLD OLLIER: Recherches expérimentales sur la production artificielle des os au moyen de la transplantation du périoste, etc. Journal de la physiologie de l'homme et des animaux, tom. ii., 1859, pp. 1, 169, 468.

LÉOPOLD OLLIER: Recherches expérimentales sur les greffes osseuses. The same, tom. iii., p. 88, 1860.

PAUl Bert: Recherches expérimentales pour servir à l'histoire de la vitalité propre des tissus animaux. Annales des Sciences naturelles, Ser. V., Zoologie, tom. v., 1886.

Von Recklinghausen: Die Wiedereriengung (Regeneration) und die Ueberpflanzung (Transplantation). Handbuch d. Allgem. Pathologie des Kreislaufs ans Deutsche Chirurgie, 1883.

Trembley: Mémoires pour servir à l'histoire d'un genre de Polypes d'ear douce, 1744.

Landors : Die Transfusion des Blutes; Leipzig, 1875.

ADolf Schмiтt : Ueber Osteoplastik in klinischer und experimenteller Beziehung. Arbeiten aus der chirurgischenklinik der Königl. Universität, Berlin.

PoNFICK : Experimentelle Beiträge zur Lehre von der Transfusion. Virchow's Archiv., vol. lxii.

Beresowsky : Ueber die histologischen Vorgänge bei der Transplantation von Hautstïcken auf Thiere einer anderen Species. Ziegler's Beiträge zur pathologischen Anatomie und zur allgemeinen Pathologie; Jena, 1893. 
Formerly, indeed, many biologists, relying upon the optical appearances presented in microscopical investigation, have been inclined to the view that the visible qualities of a tissue, as revealed by the microscope, were the only, or the chief, distinctive characters. For instance, by microscopical investigation one cannot distinguish the tendons, nerves, bones, and cartilages of a dog from the corresponding tissues in a horse. So far as their special use in the organism goes, one might interchange the corresponding parts in these two mammals. A tendon from the dog, if large enough, might be attached to the muscle of a horse, and would transmit the pull of the muscle on the bone just as well, and would completely satisfy the mechanical duties of the horse's tendon. The same might happen in the case of a bone, of a cartilage, or of a nerve-fibre.

As a matter of fact, the idea that parts of the tissues of different animals may serve to replace one another has been employed repeatedly in science, especially in the science of medicine. But I believe that our ideas are not yet clear upon the matter. The erroneous impression to which I have alluded has arisen because we do not bear in mind that each tissue, each part of an organ, each cell, possesses, in addition to its obvious characters, very many characters that are invisible to us. Such characters are inherent in the tissue-cells because these are parts of a definite organism. In consequence of their specific tissue characters, which are visible to us, we assign cells their place in histo- 
logical classification; in contrast, we may denote the other characters as constitutional, or species, characters.

No doubt tissue cells are in the same case as genital cells. So far as microscopical characters go, egg cells and spermatozoa are wonderfully alike in all the mammalia; in many cases we could not distinguish between those of different animals. But, because they bear the specific characters, we cannot doubt but that they are as distinct as are the species, although invisibly to us.

The products of the sexual cells show us clearly enough that out of each kind of egg only its own species of organism can be developed. Certainly it is not so plain that, besides their visible microscopical characters, the tissues and organic parts are in possession of more general characters, identical in all the differently-specialised tissues of a single organism; but we may infer the existence of such latent characters, at least partly, from the results obtained, in the case of plants, by grafting, in the case of animals, by transplantation and transfusion.

In the case of plants one may graft a twig cut from one tree upon the stem or lower part of another tree of the same kind, and so bring about a firm and lasting union between the two. In a short time the corresponding tissues of the parts brought into connection quietly unite. Thus from two different individuals a single living organism may be produced artificially. 
One would expect, therefore, that a twig and stem, chosen from two closely allied species, such as, for instance, the pear and the apple, would unite when the suitable tissues were put together. But this does not happen. Successful grafting depends far less on the conjunction of obviously appropriate parts than upon characters unrecognisable by us, such as deep-seated kinship between the parts, and the specific characters of their cells; while in the case of individuals of the same species two pieces will unite even if they are not brought together in appropriate conjunction, or when they belong to different parts of the organism, as, for instance, to the root and the leaf; yet in the absence of deep-seated kinship union will not take place.

Generally this kinship, which has been called vegetative aftinity, depends, like sexual affinity, upon the degree of systematic relationship. It appears that the same condition of things occurs as when, in ordinary fertilisation, sexual cells from different varieties, or species, are united. In both cases it happens, on the average, that union is the more to be expected the more closely the plants concerned are akin, in a natural system of classification.

But in grafting, as in cross-fertilisation, unexpected exceptions to this rule occur. Relying upon these, Naegeli thought that the external distinguishing tokens do not always indicate correctly the intrinsic constitutional differences. Frequently 
union will not take place between plants most near akin in classification, most alike in external characters; while it will occur between plants most different in outward aspect and belonging to different genera or even families. In other words, external characters give no certain index to the degree of vegetative affinity or of sexual affinity between two kinds of plants.

As an example of this, Vöchting, in his treatise upon transplantation of plant-tissues, takes the tribes of pear-trees. Grafting between these and apple-trees takes place only with difficulty, although the apple is a close kinsman and belongs to the same genus. On the other hand, most of them graft easily upon the quince, although that belongs to a different genus. In this case, also, there is no sexual affinity between the pollen and the ova. Hybrids are not formed between the pear and the apple.

It seems probable to me, although as yet I cannot get complete proof of it, that sexual and vegetative affinity, that is to say, the relationship between the egy-cell and the pollen of two species, and the relation between twig and stem, depend upon the same intrinsic qualities of that elementary organism the cell.

Vöchting distinguishes as harmonic or disharmonic the modes of union between twig and stem, according to whether or no they reach the formation of functional unity. Among cases of disharmony there are several interesting gradations. Generally speaking, in the case of plants 
not adapted to each other, no attempt at union occurs, and the grafted twig speedily perishes; sometimes even the stem dies, as if it had been poisoned by the graft. In other cases the disharmony is not shown so strongly. The twig and the stem begin to unite, but, sooner or later, disturbances occur, and complete destruction results. According to Vöchting, in the case of some Cruciferce the disturbances are as follows: the twig begins to form roots at its lower end, and these grow into the stem of the host. Through them the twig uses as food the juices and salts of the stem, refusing to unite with the stem so as to form a single individual. As Vöchting says, this formation of roots simply is an attempt on the part of the twig to complete its own individuality. Instead of growing into corporate union with the stem, the twig attempts to become a parasite upon it. A further consequence often is, that the stem, too, begins to respond to the unadaptive stranger's influence. Thus, when Vöchting grafted a Rhipsalis paradoxa on an Opuntia labouretiana, he found that round the roots of the graft the tissues of the host threw out a protective sheath of cork, or turned in places to a gelatinous mass.

In some cases experimenters have overcome disharmony between two species, $\mathrm{A}$ and $\mathrm{B}$, by making use of a third species, C, with a vegetative affinity for both $\mathrm{A}$ and $\mathrm{B}$. Thus, an intermediary between the two disharmonic forms is made, and by such an arrangement a single functional individual is produced from pieces of three different species. Thus, 
upon A, as stock, a shoot of C is grafted, while upon this shoot of $\mathrm{C}$, as stock, a shoot of $\mathrm{B}$ in turn is grafted.

In the matter of these different grades of disharmony, a comparison may be made between sexual and vegetative affinities. In many cases the spermatozoa of one species will not impregnate the eggs of another species. In other cases, the alien spermatozoon may penetrate the egg and unite with its nucleus, making, however, an unsatisfactory combination in various degrees of infertility. Sometimes the fertilised egg divides only a few times and then dies; sometimes development proceeds to the stage of the blastula, the gastrula, or even further; but it then comes to an end, through intrinsic causes beyond our ken, and, finally, complete destruction follows.

Our acquaintance with what happens in transplantation of animal tissues is smaller than in the sphere of botany.

Long ago, Trembley attempted to cause, by grafting, the union of two pieces of hydroid polyps into a single individual. He divided, across their middles, two specimens of Hydra fusca, and then, in a watch-glass, applied the upper end of one to the lower end of the other. In one case he was rewarded by the occurrence of complete union; for, after a few days, on feeding the upper end with a worm, it was passed on into the lower end. Later on buds arose, both above and below the point of union. Trembley, however, was unable to graft on each other parts of different species, parts of the 
green hydra, Hydra viridis, upon the common hydra.

Transplantations of single tissues or organs have been made more often, and by several investigators. I shall mention only the older results of Ollier and MI. Bert, and those made in 1893 by A. Schmitt and Beresowsky.

Ollier exposed the bone of an animal, and, carefully removing a part of the periosteum, planted it in the connective tissue under the skin in another part of the body. The consequences differed according as the transplanted tissue was imbedded in another animal of the same species, or of another species. In the first case the piece of periosteum grew, obtaining a supply of blood from vessels which grew out into it from the surrounding connective tissue in which it was embedded. In a short time lamellæ of bone were formed by the layer of osteoblasts, so that a small plate of bone was formed under the skin. This, however, proved always but a temporary structure, for, being formed in an inappropriate spot, and, therefore, being functionless, it was soon reabsorbed. In the second case, however, in which the piece of periosteum was removed from the bone of a dog and planted in a cat, rabbit, goat, camel, or fowl (or vice versâ), formation of bone did not occur; either the piece of periosteum was absorbed, or set up suppuration around it, or became enclosed in a cyst.

Paul Bert's experiments were the following. He removed pieces two or three centimetres long from the tails of white rats a few days old, skinned each 
piece, and planted it in the connective tissue under the skin of the same animal. In a few days circulation of blood was established in the pieces of the tails, by union with vessels from the connective tissue in which they were embedded. Muscles and nerves degenerated, but the other tissues, bones, cartilages, and connective tissue, grew vigorously, so that, in animals killed and examined a month after the operation, the pieces of tail, implanted when they were two or three centimetres long, had grown five to nine centimetres long.

The result was totaliy different when the transplantation was made from one species to another. When the tip of the tail of a Mus decumanus or a Mus rattus was transplanted to a squirrel, guineapig, rabbit, cat, dog (or vice versâ), either extensive suppuration took place, and the piece was extruded, while sometimes the subject of the experiment died; or, after a less turbulent course, the alien piece was absorbed. The continuance of life and growth in the piece only took place when the two animals concerned were allied very closely. Thus success followed transplantation from Mus rattus to Mus decumanus (or vice versâ), but not when it was from Mus sylvaticus to Mus rattus.

The recent experiments of A. Schmitt and Beresowsky lead to the same conclusion. The former succeeded in making pieces of living bone 'take' only when the transplantation was from one individual to another of the same species, or to another part of the same individual. Beresowsky transplanted pieces of frog's skin to the $\operatorname{dog}$ and the 
guinea-pig, and pieces of dog's skin to the guineapig, and always found that they died, or were thrust out as foreign bodies.

Precisely the same results follow transfusion of blood between animals of different species. There is complete agreement among investigators. When the blood is made to flow directly from the vessels of one animal to the vessels of an animal of a different species, as from the dog to rabbit, or from dog to sheep (or vice versâ); or when it has been first freed from fibrin and then injected, the result is always the same. 'We have always found,' says Ponfick, summing up the results of the investigation, 'not only that blood of another species acts in strong doses as a poison, and in weaker or smaller doses is harmful, but that (and this seems to me my most important result) in every case the bloodcorpuscles are destroyed almost completely, probably quite completely.' In a very few minutes, in the case of disharmonic kinds of blood, the red corpuscles degenerate, and the hæmoglobin, becoming dissolved in the blood-plasma, soon appears in the urine. In the case of transfusion of similar blood between individuals of the same or of very closely related species, the hæmoglobin does not appear in the urine except after very large doses; and Ponfick infers that the red blood-corpuscles, either all of them or most of them, remain unchanged in the new animal.

Landois has carried out transfusion between the remotest species, between different families of mammals, and between mammals, birds, and 
amphibia; from these he drew 'the inference, important for classification of animals, that those animals anatomically most nearly allied have their blood most closely alike.' In fact, ' the destruction of the foreign blood happens the more slowly the more nearly the animals are allied.' ' Thus, in doubtful cases, experiments on transfusion might settie degrees of relationship. Between individuals of the same species transfusion is a complete success; when the species are closely allied, the transfused blood disappears only very gradually, and large quantities may be transfused without harm. The further apart the animals may be, in a system of classification, the more violently the destruction of the foreign blood takes place, and the smaller is the quantity that can be endured in the vessels. Thus, in the extent to which blood transfusion may occur, I see a step towards the foundation of a Darwinian theory applied to cells.'

As yet, transplantations and transfusions between animals of different species have been considered with a view to their importance in surgery and in medicine, rather than from their purely physiological side. From the results given above, in which I believe, although there might be drawn from literature contradictory results -in which, however, I cannot feel confident-I am prepared to extend a conclusion to the animal kingdom that is better supported in botany: the conclusion that the cells and tissues possess, in addition to their definite microscopical characters, more general, intrinsic, specific characters, and that one inay speak 
of the vegetative affinities between tissues exactly as one speaks of the sexual affinities between reproductive cells.

SUMMARY OF THE CONCLUSIONS IN THE FIRST SECTION.

Summing up what has been said in the preceding pages, we find a large series of facts supporting our contention that cells multiply only by doubling division. First comes the fundamental circumstance that single-celled organisms exhibit only doubling division, as by that alone the permanence of species, which experience shows us to exist, is possible.

Secondly, some facts of reproduction were considered. The formation of germinal tissues, and, in the case of lower plants and animals, the occurrence of budding in almost any part of the body, are easily intelligible if every cell, like the egg-cell, has been formed by doubling division, and so contains the rudiments of all parts of the organism; and if thus, on the call of special conditions, every cell may become a germ-cell again.

Thirdly, great stress is to be laid on those experiments in which the process of development was interfered with at different stages, as these showed that the separate cells which arose by division were not predestined unalterably for a particular rôle, according to a predetermined plan (facts of regeneration and heteromorphosis).

Fourthly, the results of grafting, transplantation, and transfusion indicate that the cells and tissues 
of an organism possess, in addition to their patent microscopical characters, latent characters, which show themselves to be peculiar to the species.

How does Weismann attempt to reconcile his hypothesis of differentiating division with these facts? By the provision of different complementary hypotheses, which, as we have seen, amount to this, that he allows the set of rudiments which he had turned out by differentiating division of the cell to creep in again by a back-door. He accomplishes this by his idea that the germplasm may undergo, simultaneously, doubling and differentiating division. In these cases cell-division has a double aspect. According to Weismann, this is possible, because the egg contains many, sometimes as many as a hundred, $i d s$, each of which is a combination representing the species. Weismann believes that in an egg, while it is preparing for its first division, the $i d s$ are arranged in two groups - an active army and a reserve army. By differentiating division the active army is broken up into the divisions, brigades, and regiments of determinants appropriate to the separate groups of cells, and so the course of the development is conducted according to a preconceived plan. On the other hand, the passive, reserve army multiplies by doubling division, and is sent along with definite parts of the active army as baggage in a fixed or inactive condition, so that it has no influence upon the normal course of development nor upon the characters of the cells (fixed germplasm, inactive, accessory idioplasm, bud-idioplasm). 
In spite of this purely arbitrary, complementary hypothesis, the facts seem to me to show that Weismann assumed an untenable position when he attributed a reserve army of 'stable plasma' only to the sets of cells in which it was necessary to suppose its existence. The experiments of Driesch, Wilson, and myself show that a complete embryo may spring from a half or quarter of the egg, and that the set of nuclei first to arise may be shifted about in the egg like a heap of billiard-balls. In the face of such facts there seems nothing left for the theory of Weismann but to endow every cell with accessory germplasm to prepare it for unforeseen events. This, however, would sterilize the other part of the theory, the doctrine of determinants, and the mechanism of development dependent on a rigid architecture of the germplasm. Consider the confusion that would arise when the deploying of the active army was disarranged by external influences, now in one fashion, now in another, if the reserve army, with its store of latent rudiments, had to come to the help of the broken pieces. What would compel the rudiments disposed to activity according to the prearranged plan to become latent where they were no longer wanted? And what would stir into activity in the necessary places the originally quiescent rudiments of the reserve army? In fact, if the rôles of activity and quiescence are even once to be exchanged by the rudiments in the cell, what object is there in drawing a distinction so sharp between the two armies-the active army which carries out the 
process of development according to a plan prearranged in its minutest details, and a passive reserve army ordered into quiescence and carried as baggage?

But here we come upon the scarlet thread that continuously has traversed the theory of germplasm in all its changes. Weismann attaches the greatest importance to the distinction. The twofold nature of the process of development is a cardinal point in his theory, linked to his doctrine of immortality for unicellular organisms and germ-cells and mortality for somatic cells.

Between somatic cells and reproductive cells Weismann places a gulf that cannot be bridged. Only the reproductive cells contain real germplasm, and only these contain the conditions for maintaining the species, as they alone serve for the starting of new generations of development. The somatic cells, on the other hand, are endowed only with fragments of germplasm, and hence they are incapable of preserving the species, and are doomed to death. The reproductive cells, like unicellular organisms, are regarded as immortal, the somatic cells as mortal, According to Weismann, cells cannot pass from the one category to the other.

As I see Nature, this contrast has been artificially reasoned into her. From several reasons, I do not think that it exists. In the first place, I consider that the facts I have given show the hypothesis of a differentiating division of cells and germplasm to be not proven and arbitrary. Next, 
the reproductive-cells must be considered as much a part of the organism as any other tissue. Sometimes they form the greater part of the body, as in many parasites, and, like the other tissues, they are subject to death, unless the conditions necessary to their further development have occurred in time. But under such conditions other cell-complexes may have death averted from them, as, for instance, when a slip cut from a willow-tree is planted. Thirdly, the reproductive cells are derived from the ego-cell just in the same way as other tissue cells are derived from it. Like tissue cells in multicellular organisms, they arise by the specialisation of material separated from the eggcell, and, like every other organ, attain the position assigned them in the plan of development in the course of the general metamorphosis of position that all the cells pass through. Often the sexual cells, like those of other tissues, appear at a distance of several cell-generations from the egg. The intervening generations are specially numerous in those animals and plants in which several sexless generations come between the sexual generations (e.g., many plants, cœlenterates, worms, tunicates).

I cannot agree to the existence (in Weismann's sense) of special germ-tracks. Naturally, I do not deny that the sexual cells arise from the egg after definite sequences of cell-divisions; but this happens in the case of all specialised cells, such as muscle, liver, kidney, and bone cells. The conception of special germ-tracks has no more significance than there would be in the conception of 
muscle, liver, kidney, and bone tracks. Though Weismann associates with germ-tracks the idea that germplasm travels along them, proof of this has yet to be brought forward.

Finally, a word about the meaning of 'immortal.' In a scientific work the word must be used in a philosophical sense. In calling a being immortal one implies both individuality and indivisibility. This, at least, was the view of the old philosophers, who have defined the idea of immortality. Thus says Leibnitz in his Theodice: "I hold that the souls which one day become the souls of men existed already in the seed, that they have existed always in organised form in the ancestors, back to Adam - that is to say, to the beginning of things.'

In his doctrine of immortality, Weismann has not concerned himself with the two implicationsindividuality and indivisibility. He calls a unicellular organism immortal, simply because its life is preserved in the organisms arising from it by division. The immortality of the unicellular forms depends upon their divisibility, upon a property which, according to the philosophical use of the word, is incompatible with immortality. According to Weismann, one immortal organism gives rise to several immortal organisms, but, as these are subject to destruction by external agents, the separate individuals are mortal. The unicellular organism is not immortal in itself, but only in as much as it may give rise to other organisms. In this way Weismann comes in conflict with the idea of individuality, and is compelled to transform his 
conception. For he says 'that among unicellular organisms there are not individuals separated from each other in the sense of time, but that each living being is separated into parts so far as space is considered, but is continuous with its predecessors and successors, and is, in reality, a single individual from the point of view of time.' Consequently Weismann must take the same view of the germcells, which, according to his theory, are immortal in the same way as unicellular organisms, and, in the same sense, he must make a single individual of all the germ cells arising from a single germ cell, and, with them, of all the organisms developed out of them. Adam is immortal quite as much as unicellular organisms, for he survives in his successors.

In briet, Weismann assigns immortality not to the unicellular individual, but to the sum of all the individuals arising from it, all the individuals of the same species, living contemporaneously and successively - in fact, to the conception of a species,

In my view, what Weismann has tried to express by the word 'immortality' is no more than the continuity of the process of development. So he himself says in the course of a defence in which, however, he did not intend to give up the standpoint he had taken; he wishes to imply, by the immortality of unicellular organisms, only 'the deathless transformation of organic material,' or 'a transformation of organic material that always comes back to its original form again.'

Thus, Weismann himself really has implied that his distinction between immortal unicellular organ- 
isms, immortal germplasm, and mortal somatic cells, is a misconception. For the continuity of the process of development, or the mode of transformation of organic material, depends upon the continual formation and eventual destruction of newly-formed material, but in no way implies the continuous existence of the organised material in a state of organisation. From this point of view, the immortality of unicellular organisms and of the germplasm breaks down, and, above all, the artificial distinction between somatic cells and reproductive cells. For, in the latter, the organic process of development, with its transformation of organic material, also occurs.

Here I may give the conclusion of this division of my argument. Cells multiply only by doubling division. Between somatic cells and reproductive cells there is no strong contrast, no gulf that cannot be bridged. The continuity of the process of development depends upon the power of the cells to grow and to divide, and has already been set forth in the sayings-Omnis cellula e cellula, omnis nucleus e nucleo. Whatever novelty the doctrine of the continuity of the germplasm brings into this saying depends upon error, and is in contradiction to known natural facts.

\section{Arguments against the Doctrine of DETERMINAN'TS.}

Weismann has united his doctrine of determinants with his assumption of a differentiating division. He conceives that every little group of cells in the 
adult body possessed of definite character and of definite position in the body-in fact, every group of cells that is independently variable-is represented in the egg and in the spermatozoon by a number of little particles - the biophores - and that these, joined in a system, form the determinants. The innumerable determinants, he thinks, are so arranged in the germplasm, and are endowed with such powers, that, during the process of development, they reach, at the right time, the right place for their expansion into cells. For instance, in the case of a mammal with parti-coloured fur, as many architecturally arranged determinants would be present as there were different spots and stripes in the fur, due to colour and length of the hairs.

This chain of ideas, made sharp and definite by Weismann, has recurred again and again in theoretical biological literature in a vague way. In my view, it rests upon a false use of the conception of causality, and upon a false implication given to the relation between the rudiment and the product of the rudiment, each mistake involving the other.

Because, if its development be not interfered with, a definite egg necessarily gives rise to a definite kind of animal, a complete identity between the rudiment and the product, between cause and consequence, has been assumed more or less consciously. The conception of the sequence has been as if an organism caused its own development in a closed system of forces, in a kind of organic perpetual motion. It has been overlooked that, in the course of the development, many other con- 
ditions must be fulfilled, as without them the product never would come from the rudiment.

That the same adults may come from the eggs depends upon the egg-cells, in the ordinary course of events, being in similar conditions of anabolism and katabolism, being affected by gravity, light, temperature, and so forth, in the same way. Thus, when we are attempting to grasp the fundamental nature of the course of organic development, we must not omit the part played by these factors.

We may dwell for a moment upon this weighty point, as its significance is commonly misunderstood.

The course of each organic development depends. in the first place, upon the absorption and metamorphosis of matter. Inorganic matter perpetually is being turned into organic material to serve for the growth and development of the rudiments. Thus, what in one stage of the development is mere inorganic material, and an external condition of the development of the rudiment, in the next stage is become a part of the rudiment. The food-yolk of an egg, for instance, like the oxygen of the atmosphere, appears, in its relation to the material of the rudiments, to be something supplied from outside, an external condition of the development; yet it is continually passing into the rudiments and altering them, even though the alteration may be purely quantitative. From this follows the very simple inference that during the course of an organic development external matter is always being changed into internal matter, or that the rudiments 
are continually growing and changing at the expense of the surroundings.

Now, let one reflect that the egg and the adult are two terminal states of organised material, and that they are separated from each other by an almost inconceivably long series of connecting, intermediate states; consider that each stage of the development is the rudiment and the producer of the succeeding stage, of the stage that follows, as the consequence of it; consider that what was external in each antecedent stage has entered the rudiment and become part of it in the succeeding stage. Then it will be understood that it is a logical error to assume that all the characters present in the last link of the chain of development have their determining causes in the first link of the chain. The mistake lies in this: in the failure to distinguish between the causes contained in the egg at the beginning of the development, and the causes entering it during the course of development from the accession of external material in the various stages. As there can be no absolute identity between rudiment and product, it is erroneous to transmute the visible complexity of the final stage of the development into an invisible complexity of the first stage, as the old evolutionists did, and as the new evolutionists are attempting to do.

But there is another error in the doctrine of determinants. This is in intimate union with the error just discussed, and, to put it shortly, consists in attributing to a cell-and the egg and sperma- 
tozoon are cells-the possession of characters not peculiar to cells, but resulting from the co-operation of many cells.

The characters of an adult active organism, like a plant or an animal, are exceedingly numerous, most varied in their nature, and essentially different. Some characters depend upon the healthy co-operation of nearly all the parts of the body, or of a group of organs; others are peculiar to an organ, and may be referred to its shape, structure, position, function, and so forth. Others, again, depend upon individual cells, or even upon separate parts of cells. Is it really possible that all these characters, so many and so heterogeneous, have special, material bearers in the germ, and that these bearers are either simple biophores or determinants - that is to say, groups of biophores?

I can conceive a cell as endowed only with the material bearers of such characters as really belong to a cell itself. Thus, a reproductive cell might have material particles as the rudiments for producing horn, chitin, chondrin, ossein, pigment, or chlorophyll, or for nerve-fibrils, muscle-fibrils; but not for producing a hair, or a separate ganglion of the spinal cord or the biceps muscle. The rudiments for hairs, nerve-ganglia, muscles, and so forth, must be groups of cells, for only groups of cells, and not specially arranged groups of particles within a cell, are able to grow into hairs, spinal ganglia, or muscles.

In a short statement, made in 1892, I said: "The mistake into which speculations upon the nature of organic development has led so many investigators 
is this: they reflect the characters of the adult upon the undivided egg, and so people that sphere of yolk with a system of tiny particles, corresponding to the parts of the adult, qualitatively and in spacial relations. But in this method of thinking, it is left out of count that the egg is an organism which multiplies by division into numerous organisms like itself, and that, in each stage of the development, it is only by the mutual action of all these numerous elementary organisms that the development of the whole organism slowly proceeds.'

Weismann himself, in a discussion of the pangenes of De Tries, has partly shown that one cannot assume the existence in the cell of material particles that are the bearers of qualities foreign to the nature of a cell and transcending it. In reference to the attempt to explain zebra-striping by pangenes, he says (Germplasm, English edition, p. 16): "There can be no "zebra-pangenes," because the striping of a zebra is not a cell character. There may perhaps be black and white pangenes, whose presence causes the black or white colour of a cell; but the striping of a zebra does not depend on the development of these colours within a cell, but is due to the regular alternation of thousands of black and white cells arranged in stripes.' Again (p. 17), he says: 'The serrated margin of a leaf, for instance, cannot depend on the presence of "serration-pangenes," but is due to the peculiar. arrangement of the cells. The same argument would apply to almost all the obvious "characters" of the species, genus, family, and so on. For 
instance, the size, structure, veining, and shape of leaves, the characteristic and often absolutely constant patches of colour on the petals of flowers, such as orchids, may be referred to similar causes. These qualities can only arise by the regular cooperation of many cells.'

Notwithstanding so correct a declaration, Weismann himself, in his doctrine of determinants, has fallen into the error he himself has exposed. To represent characters of the adult due to groups of cells and organisms, he imagines in the egg-cell, not simple particles like pangenes, but architecturally arranged groups of particles, determinants.

No real change has been made. Conditions are reflected upon the cell that in their real nature surpass its possibilities. With right and reason one may adduce, against his own determinants, what Weismann has said about pangenes, for exactly the same reasons: 'There cannot be zebra-determinants or serration-determinants, because zebra-striping, like the serrated edge of a leaf, is no cell character.'

The error in Weismann's doctrine of determinants may be made clearer by an analogy.

The human state may be conceived as a high and compound organism that, by the union of many individuals, and by their division into classes with different functions, has developed into a form always becoming more complicated. To carry out our comparison better, let us assume that all the individuals united in the human state arose from a single pair. The single pair would be the rudiment of the whole state, and would bear the same signifi- 
cance in the development of the state, as the fertilised egg bears to the development of the adult. The characters of the state, its different organisations for protection, for tilling the soil, for trade, for government, and for education, must be explained causally from the characters of the first pair, which we take as the human rudiment, and from the outer conditions under which that pair and the generations that arose from it had to live.

As the state develops, urban and district communities, unions for husbandry and manufactures, colleges of physicians, parliaments, ministries, armies, and so forth, appear. All this visible complexity depends upon individuals associated for definite purposes and specialised in different directions. It would certainly not occur to anyone to explain the growth of this complexity in the developing state by the assumption that this secondary complexity was preformed as definite material particles present in the first pair, although the first pair is the rudiment of the whole. Much comment is unnecessary; everyone must feel that this attempt to explain the causal relations is on the wrong track, that it is perverse to try to explain the complex characters of the human state by a system of architecturally arranged particles stored within the first pair. The organisations arising from the co-operation of many men are something new, and cannot be regarded as present in the organizations of one man. No doubt they depend, in the last resort, upon human nature, but by no means in this crude, mechanical fashion. 
But what applies to the causal relations between the state-organism and men applies also, ceteris paribus, to the explanation of the causal relations between the rudiments in the egg and the organism to which the egg gives rise. For these an explanation cannot be expected on the lines of Weismann's doctrine of determinants, as that implies a fundamentally erroneous assumption. It refers organizations that depend upon cell-communities to organizations of material particles within a cell.

'To understand inheritance,' says Naegeli, with truth, 'we require not an independent, special symbol for every difference resulting from time, space, and quality, but a substance that, by the linking of the limited number of elements in it, can exhibit every possible combination of differences, and that by permutation can pass into another combination of differences.'

This standpoint is clearer when interpreted in terms of cells. The hereditary masses contained in the egg and spermatozoon can be composed only of such particles as are the bearers of cell-characters. Every compound organism can inherit characters only in the form of cell-characters. The innumerable, and endlessly variable, characters of plants and animals are of composite nature. They find their expression in differences of shape, structure, and function in the organs and tissues, and in the special methods in which these are interrelated. They depend upon the co-operation of many cells, and, for this reason, cannot be carried into the hereditary mass of any cell by material bearers. 
They are secondary formations, that can arise only after the multiplication of cells, and from the varied combination of cell-characters that accompanies the multiplication of cells.

In the foregoing pages I have attempted to prove the untenability of the doctrine of determinants from general considerations. I shall now attempt the same by analysis of a concrete case. The frog's egg may serve for this. It is a familiar object, frequently studied. Consider its mode of division, and the formation of the blastula, gastrula, and germinal layers.

In cleavage the nucleus plays the chief part, and thus has been accepted as the bearer of the hereditary mass. But no single, special determinant gives the impulse for cleavage; rather, the cooperation of all the particles that are essential to the nature of the nucleus. The chromosomes, which we may regard as independently growing and dividing units, must have doubled by assimilation of food material from the yolk ; perhaps, also, the centrosome may have doubled in the same way before the nucleus is in a condition to divide. This condition itself appears the necessary result of many difierent processes of nutrition and growth, as the result of complicated chemical processes that run their course within the separate, elementary, vital units of the nucleus.

The multiplication of the nucleus into two, four, and eight daughter-nuclei, and so forth, gives the impulse for the breaking up of the yolk into a corresponding number of cells. In that process 
the direction of the cleavage-planes, the relative positions and the different sizes of the cells exhibit, under normal conditions, the most marked regularity. But it may be shown directly that this regularity is not the result of special determinants lying within the nucleus. For all these phenomena, which are characteristic in the cleavage of the frog's egg, as well as in the cleavage of all other eggs, are determined directly by the qualities of the yolk surrounding the nucleus.

In several publications I have shown clearly that the external form of an egg and the arrangement of its contents, according to the different specific gravities of the component particles, determine the position of the nucleus and of the successive planes of division. Similarly, the different sizes of the cells first formed and the unequal rate of division shown at the two poles of the egg depend upon the constitution of the yolk, upon the cleavage of the yolk into a portion richer in protoplasm and a portion poorer in protoplasm, and upon the differences in the bulk of protoplasm that in this way reaches each of the first-formed cells.

In many cases it has been shown that there is a constant relation between the first three cleavageplanes of the egg and the long axis of the animal that arises from the egg. Weismann and Roux make this a proof that, in nuclear division, the nuclei that arise have different qualities; that the protoplasmic masses lying to the right and left of the median plane are set apart to build up the right and left halves of the embryo ; that, similarly, 
the first transverse and horizontal cleavage-planes divide the protoplasm of the egg into pieces predetermined for the formation of the anterior and posterior, dorsal and ventral, parts of the embryo.

But I think I have shown beyond possibility of doubt that these events are due not to the existence of special, mysteriously working groups of determinants within the nucleus, but merely to the specific shape of the whole egg and to the segregation of the yolk. It is self-evident that, as the body of the embryo builds itself up from the actual material of the egg, the way in which the material of the egg is disposed must be of great influence upon the formation of the shape of the embryo. And so, in a recently published work, I stated that the growing embryo, especially in its early stages, must conform in many ways to the shape of the fertilised egg.

Thus, to bear out what I have been saying by actual examples, the distribution of the actual particles of the fertilised egg must correspond to the disposition of the bulk of material in the blastosphere; for, in the breaking up into cells, the spacial arrangement of the substances of different weights undergoes no change. Thus, amphibia, the eggs of which have the poles different in character, produce blastospheres the poles of which are unlike; while eggs, like those of the fowl, where the yolk does not divide, give rise to blastospheres with unsegmented yolk. In such cases the more or less complete segregation of the yolk and gravity, which causes a separation of 
the contents of the egg according to the weights of the particles, are agencies determining the particular kind of development. It is no case of special groups of determinants within the nucleus.

Thus, an oval and an elongate egg produce respectively an oval and an elongate blastosphere. The blastosphere determines the orientation of the gastrula, and so forth. In fact, the original distribution of mass in the material of the egg is carried directly on to the following stages of development (oval eggs of triton, insects, etc.).

So, tinally, in many eggs, where, in addition to a polar differentiation, there is also a bilateral symmetry in the distribution of substances of different specific gravities and of different physiological value, the resulting blastospheres, from the reasons given above, assume a bilaterally symmetrical form.

Although, then, in eggs with polar differentiation, which have either one axis longer or are bilaterally synmetrical, under normal conditions the planes of the first two segmentations may correspond to the principal axes of the future embryo, the cause for this agreement lies in the structure of the egg, and is not to be looked for, as Roux and Weismann suppose, in differentiating processes of cleavage, undergone by the nuclei in their first divisions. It is in this way that there are to be explained the investigations made by Van Beneden and Juilin upon the eggs of ascidians, by Wilson upon the egg of Nereis, by Roux upon the egg of Rana esculenta, and by me on the egg of T'riton.

As it fails with the process of cleavage, so Weis- 
mann's doctrine of determinants fails when we analyse the formation of the blastosphere, the gastrula, and the germinal layers.

'The formation of the blastosphere seems to me to be due to the co-operation of the following processes :

(1) In the division of the egg-cell cavities arise between the four, eight, and sixteen pieces, and thus the whole contents of the egg become arranged more loosely. (2) The more the cells multiply by division and become smaller in circumference, the more closely they apply their lateral surfaces to each other, especially at the outer surface of the whole, so assuming the arrangement of cell-epithelia. (3) By the secretion of fluid, a constantly growing central cavity is formed pari passu with the approximation of the superficial cells, and this probably also brings with it an increase of the internal pressure, and a wider curvature of the wall of the sphere.

Now, is there any part of these processes that has to do with the breaking of the nuclear contents into groups of determinants with different qualities? By no means. The egg divides into many pieces, because such division is a general property of cells, and it is not associated with separate, special material bearers. The appearance of spaces between the cells, resulting from division, is due to forces some of which reside within the single cells, some of which come from without. In especial, the assumption of a spherical shape-an assumption occurring also to a greater or less degree when the 
results of division leave each other-is caused by the yolk actively arranging itself round the two nuclei as centres of attraction. The attempt to become spherical is opposed by other forces, in accordance with which the cells resulting from division press against each other. These forces that press the cells together seem to increase as the size of the cells diminishes, so that the cells approximate their lateral faces continually more closely. 'The secretion of fluid into the interior of the sphere and the resulting increase of the outer surface results from the characters of the whole wall, and cannot be explained by single, specially determined cells.

Finally, to take the case of the special kinds of blastospheres (e.g., of amphioxus, amphibia, reptiles, birds, and so forth), it has been already shown that these are produced by the shape of the egg, by the bulk of the yolk, and by the segregation of the yolk-particles under the influence of gravity; that, in fact, the shapes are determined by the general gross conditions of the structure of the egg.

Plainly, the blastosphere cannot be pre-existing as a structure of particles in the fertilised nucleus; there cannot be blastosphere determinants. The conditions for the origin of the blastosphere come into existence only by the process of segmentation, and it is only by its capacity to divide that the egg contains the conditions for blastosphere formation. Here we have epigenesis-the appearance of a new formation, not the becoming visible of preexisting complexity. 
The conditions of gastrulation and of the formation of the germinal layers are similar. The invagination of the blastosphere comes about by the co-operation of all the cells of its wall, by local differences in the rates of growth in that wall, from dissimilarities in its curvature, from many causes which have not yet been sufficiently sought out and investigated. As cell division itself depends not upon special particles, but upon changes in the entire nuclear contents, it follows that the growth of the blastosphere-wall, which is merely the sum of the growth of all the cells in it, cannot be determined by special groups of determinants.

As an attempt to explain gastrulation, the origin of the germinal layers and many other events of development, the doctrine of determinants has reversed cause and effect. Certain cells do not become invaginated into the segmentation cavity because they possess groups of determinants that impel them to the assumption of inner layer characters. The reverse is the truth. Local conditions of growth cause the invagination of a set of the cells of the blastosphere-wall. This invaginated layer of cells, brought into a new position with regard to its environment, becomes the endoderm and receives the stimulus to assume the character appropriate to the new environment. It is unlogical to speak of endoderm in the fashion of many textbooks and treatises on embryology, while the socalled endoderm cells still form part of the outer surface of the blastosphere, or even while they are still in process of formation by cleavage. For 
'inner germinal layer' implies a condition of position which is created by the invagination.

In fact, it is impossible, in thinking of the gastrula as in thinking of the blastosphere, to conceive that in the egg, which is a simple cell, there can be preformed by material particles in the nucleus a condition which implies the existence of two layers of cells.

Thus analysis of a special case leads to the same conclusion as is reached by the general reasoning of the earlier part of this section. 


\section{PART II.}

\section{THOUGHTS TOWARDS A THEORY OF THE DEVELOPMENT OF ORGANISMS. ${ }^{1}$}

\section{Now that criticism of the germplasm theory has given us a bias in the right direction, it is necessary to map out more clearly the path along which}

1 The second section contains references to the following treatises :

C. V. NAEgeli : Mechanisch-physiologische Theorie der Abstammungslehre (1884).

Hertwig, Oscan: Lehrbuch der Entwicklungsgeschichte des Menschen und der Wirbelthiere; 4th edit.

SACHs : Lectures on Plant Physiology; English edition, Clarendon Press.

Vonchтім : Ueber die Theilbarkeit im Pfanzenreich und die Wirkung innerer und äusserer Kräfte auf Organbildung an Pflanzentheilen. Pflüger's Archiv., vol. xv., 1877.

Ibid. : Ueber Organbildung im Pfanzenreich, 1, 2 ; Bonn, 1878, 1884.

Goebel : Beiträge zur Morphologie und Physiologie des Blattes. Bot. Zeit., 1880.

PfLÜGER: Die teleologische Mechanik der lebendigen Natur; Bonn, 1877.

MaUpas: Sur le déterminisme de la sexualité chez l'Hydatina senta. Comptes rendus des séances de l'Académie des Sciences; Paris, 1891.

Weismand : Die Allmacht der Naturzüchtung. Eine Erwiderung an Herbert Spencer; Jena, 1893. 
solution of the problem may be sought. In general terms, our problem is the necessary origin from an egg, always of the same organism, with its manifold characters, and the explanation must avoid the attribution to the egg of characters foreign to its nature as a cell. This is the more necessary as Weismann objects to the supposition that celldivision is doubling, holding that the supposition allows neither an explanation, nor even the beginning of an explanation, of the differences that arise among cells while the differentiation of the body occurs. 'Any explanation must in the first place account for this differentiation,' says Weismann (Germplasm, p. 224); 'that is to say, the diversity which always exists amongst these cells and groups of cells arising from the ovum must be referred to some definite principle. In fact, no one could even look at it as giving a partial solution of the problem, if differentiation is supposed to be due to that part alone of the germplasm becoming active which is required for the production of the cell or organ under consideration. But the higher we ascend in the organic world, the more limited does the power of producing the whole from separate cells become, and the more do the numerous and varied

Herbent Spexcer : A Rejoinder to Professor Weismann. Contemporary Review, 1893.

Ibid. : Die Unzulänglichkeit der 'Natürlichen Zuchtwahl.' Biol. Centralblatt, vol. xiv., No. 6.

Every : Die Entstehuny und Ausbildung des Arbeiterstandes lei den Ameiscn. Biol. Centralb., vol. xiv., No. 2, 1894.

HAACKe; Gestaltung und Vererbung (1894). 
differentiations of the soma claim our attention and require an explanation in the first instance. The presence of idioplasm in all parts containing the primary constituents does not help us in this respect.'

With this I cannot agree. Naturally, Naegeli, De Vries, Driesch and I assume that, of the many rudiments present in every cell, only some come to activity in each special case, and that the selection of those that become active is due to causes arising in the course of development. Our conception of the nature of these causes, and of their place of origin, is diametrically opposed to Weismann's.

Weismann would make the causes of this orderly development of the rudiments reside in the germplasm itself; for he considers that to be not only the material but the motive force of the course of development. According to him, every cell must have become what it is, because it was provided only with the definite rudiments assigned it beforehand, according to the plan of the development of the germplasm.

On the other hand, we regard the development of the rudiments as depending upon motive forces or causes that are external to the germplasm of the ovum, but that none the less arise in orderly sequence throughout the course of the development. The causes we recognise are first, the continual changes in mutual relations that the cells undergo as they increase in number by division, and second, the influence of surrounding things upon the organism. 
One may group together as centrifugal causes of the process of development the characters of the fertilised cells and the interrelations between the products of their divisions, and distinguish them from the centripetal causes, or motive forces that are provided by the action of surrounding things. None the less, it must be borne in mind that there is no sharp distinction between centrifugal and centripetal forces. On page $86 \mathrm{I}$ showed how what is external in one stage of the process becomes internal in the succeeding stage. The external constantly is becoming internal, and the sum of the internal factors increases only at the expense of external factors.

From the physiological point of view I regard the divergent differentiation of cells as a reaction of the organic material to unlike impelling forcesthat is, to factors shown by experimental physiology to be actually present and to rule the building up of the organism. 'It were superfluous to detail,' as Naegeli says, 'how continually other forces external to the idioplasm, but belonging to the individual, influence the idioplasm; every cell, indeed, as it grows and divides, takes up a definite place in the growing whole, and finds itself in a peculiar combination of conditions of organisation.' 'Not only influences within the individual affect the idioplasm, as that may be altered by external influences, and so may be forced to grow in a new direction.' 'The influence of surroundings in determining which of the rudiments contained in the idioplasm shall achieve development is shown 
in the following example: it depends on their nutrition whether certain trees shall bear foliage or flowers; while in an unpropitious climate many plants refuse to bear flowers at all, but content themselves with vegetative reproduction.'

This principle indicates the path along which explanation of the differentiation of cells is to be sought. Although in no single case is it yet possible to refer a known action to its appropriate cause-in other words, to show a definite stimulus producing a definite reaction upon the rudimentthis failure is not to be attributed to error in the principle. It is the natural result of the enormous difficulties besetting an attempt to understand the highly involved events of development. We can only ask whether or no our general principle is harmonious with the facts displayed in nature.

In the following pages I shall try to develop this view, taking, as formerly, a few instances. I shall now proceed further with suggestions I made in my treatise on Old and New Theories of Development. I start from the conception that the ovum is an organism that multiplies by division into numerous organisms like itself. I shall explain the gradual, progressive organisation of the whole organism as due to the influences upon each other of these numerous elementary organisms in each stare of the development. I cannot regard the development of any creature as a mosaic work. I hold that all the parts develop in connection with each other, the development of each part always 
being dependent upon the development of the whole.

The power of the ego to multiply by division is a chief and most important factor in the production of complexity during the course of development. It is only because the nuclear material, by a series of intricate, chemical changes, assimilates reserve material from the egg and oxygen from the atmosphere that it can give rise to continually increasing complexity within itself. The increase in bulk results in a cleavage into two, four, eight, and sixteen pieces, and so forth. The cleavage produces a constantly changing distribution in space of the nuclear material. The two, four, eight, and sixteen nuclei that arise by division diverge from each other and take up new positions inside the egg, in definite relations to each other. At first the particles of the egg were arranged around the fertilised nucleus, which was a single centre of force ; they become grouped around as many centres of forces as there are nuclei, and so become segregated into as many cells. Clearly enough, the egg, in its single-celled condition, changes its quality in a marked degree when it becomes multicellular, even although the change has occurred by doubling division.

This, so clear in the early stages of development, continues to occur throughout the later stages of growth. The continued cell-multiplication causes not only changes of bulk, but also from time to time changes in quality; for each shape is bound up with definite conditions. When the conditions 
alter, the organic material, by its power of reaction, changes its shape in a corresponding fashion.

As the nature of architectural plans depends upon the properties of the wood, stone, or iron, as they must correspond with the material to be employed (i.e., the span of a roof, the construction of a bridge depend upon the material in shape and weight), so the nature of the organic material determines to a large extent the shapes assumed in the course of growth.

Shape in many respects appears to be a function of growth in an organic material.

A few examples will make clear this important relation. A limit is set to increase in the size of a blastosphere by the nature of the material of its walls. Its wall is a membrane, composed of one or more layers of cells ; that this may preserve its curvature, a definite pressure from within must be maintained, proportioned to the cohesive force of the cells; at the same time the wall of the sphere must be able to withstand the strain and pressure put upon it by external forces. All these, and many other factors less easy to conceive, must be delicately adjusted to one another. If in any direction a definite limit be exceeded, then either the structure will be destroyed by disintegration of the component parts, or a new shape will be assumed. The latter is the event in the case of a living substance capable of reaction. The blastosphere, growing beyond its limits, folds into a cupshaped organism. Did we know all the influences affecting the wall of the blastosphere, then we 
would understand the causes by which growth beyond a definite limit must result in invagination. From the occurrence of the gastrula in all the divisions of the animal kingdom, we may conclude that it is a temporary phase, inevitable in the growth of animals.

There may be noticed here a second connection between shape and organic growth, exceedingly simple in its nature, but of fundamental importance in its consequences. It may be stated in this saying : Growth always must be such as to produce the greatest possible extension of surface. The reason of this is simple, depending on the different natures of inorganic material and living organic material.

A crystal in its mother liquor grows by attracting new particles and depositing them upon its outer surface, according to the kind of crystallisation peculiar to the material of which it is composed. These particles, once crystallised, retain their position even when new layers are deposited on their outer surfaces, and remain unchanged, perhaps, like rock crystals, for thousands of years, until changed outer forces loosen the bonds that bind them.

Organised material cannot grow in this fashion; it takes up material from without, not, like the crystal, arranging it on the outer surface, but ingesting it. Protoplasm cannot become fixed in any condition without being destroyed; it exhibits perpetual interchanges with the outer world; unceasing intake and output is a necessary accompaniment of its life. 'The growth of idioplasm,' as 
Naegeli strikingly says, 'implies a constancy of' perpetual change.'

Thus, growing protoplasm can assume only such shapes as allow it to remain in constant touch with the outer world. A cubical or spherical mass of cells could not grow by the formation of new layers of cells on the outside, for these layers would deprive the centrally placed masses of cells of their conditions of existence. Similarly, an extended membrane of cells or an epithelial layer cannot add indefinitely to its thickness, else would the cells furthest removed from the outside be injured in their relations to surrounding things. T'o satisfy its essential conditions, protoplasm can grow only with a proportionate extension of its external surfaces. 'This is secured by the cells becoming' arranged in threads and membranes, and its result is that the threads by branching, and the membranes by folding, produce structures whose complexity increases with growth.

This conception that the shape of growing organisms is in many respects the necessary consequence of the specitic characters with which protoplasm is endowed, explains the great contrast between animals and plants in their general organisation. 'The contrast is the result of the difference between animal and plant metabolism, and between the ways in which animals and plants obtain their food. Plant cells elaborate protoplasm from the carbonic acid of the air, water, and easily diffusible solutions of salts, obtained from the sea or from the soil. For the chemical work of combining 
these, they require the active energy of sunlight. iVe can now see the chief requirements to which the constitution and arrangement of the cells in a multicellular plant must be adapted. Plant cells may become clothed in a thick membrane, as that would prove no hindrance to the passage of gases and easily diffusible salts; but they must be arranged so as to present the greatest possible surface to the surrounding media (i.e., to the soil and the water, the air and the sunlight) whence is drawn their supply of matter and force. The cells must turn a broad face to the outside; this they do by becoming arranged in branching rows, or in leaf-shaped Hattened organs. That they may suck up water and salts from the soil, the cells are arranged as a highly branched system of roots, covered with delicate hairs, and penetrating the soil in every direction. To inhale the carbonic acid from the air, and to be subjected to the influence of sunlight, the aerial part of the plant stretches out its branches towards the light, and becomes folded into the flat leaves, the structure of which reveals a suitability for assimilation. Thus the whole architecture of a plant is superficial and visible; internal differentiation into organs and tissues either is wanting, or, compared with animals, is very scanty. It is only in the higher plants that the internal fibro-vascular tissues appear; these serve a double purpose : they act as channels along which the sap passes, so bringing together the different materials absorbed by roots and leaves; and they have the mechanical function of strengthening 
the stem and branches. 'The different mode of nutrition of animals results in a totally different structural plan. Animal cells absorb material that is already organised, and that they may do so their cells are either quite naked, so atfording an easy passage for solid particles, or they are clothed only by a thin membrane, through which solutions of slightly diffusible, organic colloids may pass. 'Therefore, unlike plants, multicellular animals display a compact structure with internal organs adapted to the different conditions which result from the method of nutrition peculiar to animals. A unicellular animal takes organic particles bodily into its protoplasm, and forming around them temporary cavities known as food vacuoles, treats them chemically. 'I'he multicellular animal has become shaped so as to enclose a space within its body into which solid organic food-particles are carried and digested, thereatter, in a state of solution, to be shared by the single cells lining the cavity. In this way the animal body does not require so close a relation with the medium surrounding it ; its food, the first requirement of an organism, is distributed to it from inside outwards. In its further complication the animal organisation proceeds along the same lines. The system of internal hollows becomes more complicated by the specialisation of secreting surfaces, and by the formation of an alimentary canal, and of a body cavity separate from the alimentary canal.

In plants, it is the external surface that is increased as much as possible. In animals, in obedi- 
ence to their different requirements, increase takes place in the internal surface. 'The specialisation of plants displays itself in organs externally visible-in leaves, twigs, flowers, and tendrils. 'I'he specialisation of animals is concealed within the body, for the internal surface is the starting-point for the formation of the organs and tissues.

Comparative embryology shows that, however varied the forms and functions of the numerous animal organs may be, the method of their development is remarkably similar. 'Lhere are required only the slightest variations of a few simple general laws. For these I may refer readers to a series of special investigations (Studies on the Germ-layer L'heory, Uscar and Richard Hertwig), and to the fourth chapter of my E'mbryology, "General Discussion of the Principles of Development.'

In these works and in the foregoing pages I have tried to show that the multiplication of the eggcell by division is itself a source of increasing complexity and an active principle in the determination of form, since the products of the division unite to form a higher unity. But in another way the multiplication of cells leads to differentiation among the cells arising from the egg. Although each of these resembles the parent egg, from which they arose by doubling division, yet they differ from it in one point: they are no longer a whole, but have become the subordinate parts of a higher unity, that is, of a higher organism. A cell that is no longer a whole, but the part of a whole, has entered upon reciprocal relations with other cells, and in 
the functions of its life is limited by these others and by the whole. The further this is carried the more the cell falls short of its independence as an elementary organism, and appears only as a part with its functions subordinate and in dependence upon the whole. ${ }^{1}$

Although from the point of view of morphology it has become more and more imperative to regard the cell as the unit of the higher organism, still, from the physiological point of view the higher organisms must be regarded as masses of material acting as wholes, and composed of several grades of structural parts, subordinate in function to the whole, and displaying only a limited division of capacities. And so the cell theory, according to which the cell was exalted unduly as the unit of life,

1 The assumption of doubling division does not involve the assumption that the germinal mass is unalterable. Although I do not regard the process of division as a mechanism for breaking up the idioplasm into dissimilar groups of determinants, I regard the idioplasm - and here I agree with Naegeli-as only relatively stable. In course of time external and internal forces may slowly alter it. On the one hand, the idioplasm of the reproductive cells in the course of generations may slowly alter, while, on the other hand, the idioplasm of cell groups in an organism may acquire a local character in correspondence with their different topographical and functional positions in the whole creature, and in relation to their place in the organic division of labour, just as in human communities individuals become altered by the lifelong exercise of some calling.

Nor does the doctrine of doubling divisions conflict with those conclusions of pathology according to which, in the process of regeneration, cells and tissues give rise only to cells and tissues of their own order. For further details see my treatise, $E i$ und Samen-Bildung bei Nematoden, pp. 97-99. These slight suggestions are only to prevent misconceptions. 
the centre of life, the elementary organism, must take limitation and correction from these wider views. This has already been insisted upon by many physiologists of insight-for instance, by Naegeli (see p. 30), by Sachs, and by Vöchting.

'Cell formation,' declares Sachs (Physiology of Plants, p. 73), 'is a phenomenon very general, it is true, in organic life, but still only of secondary significance; at all events, it is merely one of the numerous expressions of the formative forces which reside in all matter, in the highest degree, however, in organic substance.' 'Essentially, every plant, however highly organized, is a continuous mass of protoplasm, surrounded externally by a cell wall and penetrated internally by numerous transverse and longitudinal partitions.'

My conception receives strong support from the way in which Vöchting set forth the relations of the cell to the whole:

' Is the circumstance that a cell, separated from the organism, is able to survive and build up the whole again a proof of the independent life of the cells while in the organism? I believe it to be only a proof that the life of the organism is always dependent upon the cell, that the life is inherent in the cell, and that the life of a compound organism is merely the resultant of the vital phenomena of its single cells; but by no means that the cell when isolated displays the same functions as while it is a part of the organism. The cell while in the organism and the cell separated from the organism and self-sufficing, are 
quite different. We must regard the functions of a cell that is part of an organism, disregarding external influences, as determined by the whole organism, and only by the cell itself, in so far as that forms a greater or less part of the whole organism. When not part of an organism, the cell is independent, and entirely determines its own function. Nowhere is it easier than in this case to confuse possibilities with facts, and nowhere is the confusion more fatal. From a morphological point of view, one may confidently regard the cell as an individual; but it must be borne in mind that an abstraction has been made. Physiologically considered, the cell is an individual only when it is isolated from a complex and is independent; of this no abstraction can be made.'

According to the conception I have been explaining, cells merge their independent individuality in that of the whole, and so the force that directs their ultimate development, and that leads to their appropriate elaboration, cannot be within them, cannot reside in special groups of determinants, in the sense of Weismann. It is given by the relations in which the cells come to stand to the whole organism and to the various parts of the organism, and, on the other hand, to surrounding things. Naturally, such relations differ with the place or position occupied by cells in the whole organism, and in this way there come to be innumerable conditions making for diverging directions of development, for division of labour, and for dissimilar, histological differentiation. The 
part played by a cell, as Vöchting puts it, will depend upon the position it comes to assume in the whole living unit. To use an expression of Driesch's, dissimilar differentiation of cells is a 'function of position.' Such a conception my brother and I, in our Studies on the Germ-layer Theory, sought to establish clearly by many examples from the histology of the coelenterates and of higher animals ; such a conception for long has been clearly expressed in physiological botany.

The simpler nature of plants in structure and function makes it easy to conduct experimental observations upon this point.

I have already described how either side of the prothallus of a fern may be made to produce male or female organs, according as it is kept in the light or in the dark. Similarly, taking a willow slip, roots may be made to appear at one end by moisture and darkness, while they will not appear on the end kept in the light.

The experiments of botanists and of fruit-growers show that young buds and the rudiments of roots are indifferent structures, the further growth of which depends entirely upon the conditions in which they are placed. 'One and the same bud may grow to a long or short vegetative shoot, to a floral shoot, to a thorn, or may remain undeveloped. The same root rudiment may grow to a main taproot or may form a secondary lateral root. The conditions that determine the mode in which these structures will develop are quite within the power of the experimenter. We have shown already 
and could show further, that he is able to determine the mode of growth by cutting, bending, tying in a horizontal position, and so forth.' For such reasons, Vöchting describes plants as masses of tissue, practically plastic, and which may be moulded at the discretion of the investigator. 'For instance, in the case of Prunus spinosa, a branch may be produced in place of a thorn by cutting a growing shoot at the proper height, in spring. The buds below the point where the cut was made turn to shoots like the rest of the plant and complete the interrupted growth, while on an uncut stem they would have grown to thorns. Thus, the rudiment of a thorn has been changed to that of a shoot' (Vöchting).

Although it is more difficult to carry out experiments upon animals, some good instances are known. If a piece cut from the stem of Antennularia (a hydroid polyp) be placed vertically, in a short time new branches and new 'ronts' spring from it. In this case, again, the position of the new growths is determined by the relation in which the stem is placed to gravity. "The tentacles arise only at the end turned towards the zenith; the "roots" from the parts directed towards the ground" (Loeb).

A similar example may be taken from among vertebrates. The notochord arises from a set of cells which are in close relation with the fused tips of the blastopore. By exposing developing frog's eggs to abnormal conditions, I was able, in some cases, to produce a hypertrophy of; one of the lips 
of the blastopore. When fusion of the lips took place the normal lip united with the rim of the protruding hypertrophied lip. As a result of this the notochord and the nerve plate came to arise, not from the usual set of cells, but from those cells that, by the abnormal condition, had come to lie in the place for the notochord. The protruding cells, which normally would have developed into notochord and nerve plate, grew into a simple fold of the external skin.

Moreover, it is well known in pathology that mucous membranes may lose their proper character and assume the qualities and aspect of the external skin, when, as in cases of prolapse, fistula, etc., they have been exposed for some time to the air.

The relations of different parts to each other and to the whole are known as correlations. Correlation exists in all the stages of the development of an organism, sometimes in one way, sometimes in another. One must note very carefully that Weismann's doctrine of determinants, according to which all that happens in development follows a prearranged plan, is entirely in opposition to this correlative character of the changes that occur during development.

Here I shall give a few quotations from botanical and zoological writers:

' If the stem of a plant be cut so that it retains its roots, but is deprived of leaves and shoots, then the adventitious buds will produce new leaves and shoots. If, however, the stem be cut so as to 
deprive it of roots, then the same cells that in the other case produced leaves and shoots will now produce roots. Precisely the same occurs with a piece of the root. In fact, it appears as if the idioplasm knew what parts of the plant were wanting, and what it must do to restore the integrity and vital capacity of the individual.' 'The idioplasm in the remaining part of a plant must be affected when an important part has been removed, because the idioplasm of the lost part is no longer capable of having influence.' 'It is clear enough that necessity acts as a stimulus, and that each definite need calls into existence the appropriate reaction.'

These are Naegeli's views, and they have been elaborated by Pflüger in his important treatise on The Teleological Mechanism of Living Nature (1877).

Vöchting writes in similar fashion:

' In a tree that is growing under normal conditions, without being subjected to injury, all the organs appear in definite relation to each other: so many leaves correspond to a definite number of twigs and branches. These spring from a stem of proportionate thickness, and the stem passes into a definitely proportioned tap-root, from which arise a due array of lateral roots. In normal conditions all these organs are in equilibrium. An apple-tree, growing on the line where tilled garden ground meets a lawn, grows more vigorously on the side towards the garden. If one of the roots of an apple-tree with three main roots and three branches be amputated, then the correspond- 
ing branch will lag behind in growth, although it may not absolutely perish.' 'The equilibrium varies according to the specific nature of the tree. It is shown in one way in the oak, in another in the beech, and is different in the varieties of a species.'

Finally, consider this statement from Goebel's Treatise on the Morphology and Physiology of the Leaf: "The fact that lateral buds do not develop while the axial bud is still growing vigorously depends upon the relation between the two. That I denote as correlation of growth.'

The dependence of parts upon each other, and upon the whole, is specially clear and instructive in cases where different plant individuals are united by budding or grafting. To limit the growth of a tree, and to induce it to become dwarfed, it is necessary only to graft it upon a nearly allied but dwarf variety. When a pear-tree is grafted upon the quince, which is characterized by its dwarf-like growth, the vegetative growth of the pear is reduced exceedingly. It produces shorter and weaker shoots; all the dwarf varieties of the pear employed as wall fruits, or growing into the little pyramids spoken of in the trade as 'cordon'-trees and potting-trees, could not have been produced unless the gardener had had the quince as a natural dwarf stock (Vöchting). With the dwarfing is associated a freer and earlier production of fruit. Other kinds of fruit-trees, apples, apricots, and so forth, show the same course.

'The capacity to withstand external influences and the duration of life may be altered in the same 
way. The pistachio (Pistazia vera), cultivated in Frankfort, which is destroyed by a temperature lower than 7.5 degrees of frost, will survive 12.5 degrees if it has been grafted upon $P$. terebinthus. Moreover, when it is grown from a seedling, it may reach the age of 150 years; but when it has been grafted upon $P$. terebinthus its length of life is increased to 200 years; while, grafted on $P$. lentiscus, it reaches only about 40 years' (Vöchting).

Vöchting's experiments upon beetroot are still more characteristic. "The stem of a beet plant that bore young buds gave rise to vegetative shoots when it was united with a young, still growing root, but to a blossoming stem when it had been grafted, in spring, upon an old root.'

Similarly, animal growth is correlative in all its stages. When a muscle becomes unusually large it sets up corresponding correlations of growth in many other parts of the body. The bloodvessels and nerves supplying it become larger, and the increase in the nerves leads to corresponding increase in the nerve centres. The tendons of origin and of insertion, and the parts of the skeleton to which these are attached, must react to the increased size of the muscle by growing larger; in fact for all the parts of the animal body the conclusions which Naegeli and other physiologists drew from plants are applicable. All the different elements of the body are in definite and intimate touch with each other.

This is shown most beautifully and clearly in the extraordinarily interesting phenomena called di- 
horphism and polymorphism. These seem to me to show how very different final results may grow from identical rudiments, if these, in early stages of development, be subjected to different external influences.

Finally, I have a little to say about the sexual dimorphism that occurs so generally in the animal kingdom.

Nearly all kinds of animals appear as male or as females. These differ from each other not only in that they produce eggs or spermatozoa, but frequently in a number of more or less striking characters affecting different parts of the body, and known as secondary sexual characters. In fact, the difference between the sexes may be so great that a systematic naturalist, unacquainted with the mode of development of the creatures, might place them in different species, genera, or even families, on account of the striking differences in external characters.

As an instance, take Bonellia, a gephyrean, the strange case of which has been remarked upon by Hensen and by Weismann. The male is about a hundred times smaller than the female, in the respiratory chamber of which it lives as a kind of parasite, and appears, so far as outward shape goes, more like a turbellarian than a gephyrean. None the less, male and female are alike not only while they are in the egg, but as larvæ, and it is only towards the period of sexual maturity that the great difference between them begins to appear. So also is it with the dwarf males of the cirripedes. 
Males and females, whether they be more or less unlike, arise from the same germinal material. The germinal material itself is sexless; that is to say, there is not a male and a female germinal material. The phenomena of inheritance in the sexual generation of hybrids show this clearly. Characters appropriate both to males and to females are transmitted either by eggs or by spermatozoa. In parthenogenetic animals both male and female individuals appear at definite times from eggs produced without sexual commerce. Whether the male or the female forms be produced depends, not upon any difference in the germinal material, but on the external influences, just as external influences determine whether the bud on a twig shall give rise to a vegetative or to a flowering shoot, to a thorn or to a stem. The influence of food, of temperature, or probably of other agencies, determines in which direction the germinal material shall grow.

The experiments of a distinguished French investigator, M. Maupas, on the determination of sex in Hydatina senta, a rotifer, have given striking results.

In Hydatina, under normal conditions the eggs of certain individuals give rise always to males, of others always to females. By raising or lowering the temperature at the time when the eggs are being formed in the germaria of the young females, the experimenter is able to determine whether these eggs shall give rise to males or to females. After that early time the character of the egg cannot be altered by food, light, or temperature. 
In one experiment, in which five females not yet fully grown were kept in a room at the temperature of 26 to 28 degrees centigrade, Maupas found that, of 104 eggs only 3 per cent. gave rise to females, while in the case of other five young females of the same brood, but kept in a cold chamber at a temperature of 14 to 15 degrees centigrade, 95 per cent. of females were produced. In another experiment, young animals were kept for a few days in the cold, and then, until death, in a higher temperature. Of the eggs produced while in the cold, 75 per cent. produced females, of those deposited in the warmth, 81 per cent. became males.

With these results may be compared what happens with many plants. Melons and cucumbers, which produce on the same stem both male and female flowers, bear only male flowers in high temperatures, only female flowers when subjected to cold and damp.

In the case of many insects in which parthenogenesis occurs, the determination of sex depends upon fertilisation. Thus, among bees, unfertilised eggs give rise to drones, fertilised eggs to females.

Sexual dimorphism in still another way reveals the intimate interactions existing between all the parts of an organism in every stage of development. It is well known, for instance, that among animals the early removal or destruction of the sexual organs hinders the development of the secondary sexual characters, or even may occasion the appearance of the characters of the other sex. Old hens become cock-feathered; human eunuchs 
have the high-pitched voice and the peculiarities of the larynx found in women.

As much as sexual dimorphism, the phenomena of polymorphism show the enormous influence exerted by external forces upon correlated variation of the parts during development, and in this way upon the final structure.

In the question of polymorphism it is worth while to discuss at some length the extreme polymorphism exhibited in the case of some of the colonial animals-first, because the matter has recently occasioned an important controversy between Herbert Spencer and Weismann; and, secondly, because the discussion will serve to make still more clear the difference between my views and those of Weismann upon the nature of the process of development.

Among the colonial insects there arise, in addition to males and females, sexless individuals known as neuters. These in certain cases are very different from both males and females in structure and in social instincts.

Among bees there are the queens, sexually mature females; the workers, females whose sexual organs are rudimentary, and parts of whose bodies - the stings, the wings, the hind legs, with their pollen-collecting apparatus-are peculiarly formed; and, lastly, the males, or drones.

In many of the ant and termite colonies still greater differences exist between the different sets of individuals. In addition to males and females, there are sexless workers, and these in many species 
are of two kinds, known as workers and soldiers. The divergences of structure among the three or four forms are shown, frequently by considerable differences in size, by the presence and absence of wings, by differences in the sense-organs, the brain, and the structure of the head. In the common ant-Solenopsis fugax, for instance, as Weismann quotes from Forel-the males have more than four hundred facets on their eyes, the females about two hundred, and the workers from six to nine. Many soldiers possess enormously large and heavy heads, with massive jaws, and naturally, with the appropriate muscles much enlarged.

But as workers and soldiers, on account of the rudimentary state of their sexual organs, cannot reproduce themselves, all the three or four kinds of ants in the colony must be developed from eggs deposited by the females. In this Weismann finds the most convincing proof of the omnipotence of natural selection, and, I venture to add, for the omnipotence of his doctrine of determinants.

He says (Contemporary Review, vol. Ixiv., p. 313): 'It fortunately happens that there are animal forms which do not reproduce themselves, but are always propagated anew by parents which are unlike them. These animals, which thus cannot transmit anything, have nevertheless varied in the past, have suffered the loss of parts that were useless, and have increased and altered others; and the metamorphoses have at times been very important, demanding the variation of many parts of the body, inasmuch as many parts 
must adjust themselves so as to be in harmony with them.' 'None of these changes' (p. 318) 'can rest on the transmission of functional variations, as the workers do not at all, or only exceptionally, reproduce. They can thus only have arisen by a selection of the parent ants, dependent on the fact that those parents which produced the best workers had always the best prospect of the persistence of their colony. No other explanation is conceivable, and it is just because no other explanation is conceivable that it is necessary for us to accept the principle of natural selection.'

According to Weismann's conception, 'every part of the body of the ant' (loc. cit., p. 326) 'that is differently formed in the males, females, and workers is represented in the germplasm by three (sometimes four) corresponding determinants; but on the development of an egg never more than one of these attains to value-i.e., gives rise to the part of the body that is represented-and the others remain inactive.' This structure of the germplasm Weismann attributes to the operation of selection. 'For in the ant state' (loc.cit., p. 326) 'the barren individuals or organs are metamorphosed only by the selection of the germplasm, from which the whole state proceeds. In respect of selection, the whole state behaves as a single animal. The state is selected, not the single individuals, and the various forms behave exactly like the parts of one individual in the course of ordinary selection.'

Naturally, from the views on the germplasm 
theory and on the doctrine of determinants that I have expressed in this book, I cannot accept the explanation Weismann thus gives of the facts. It is true that Weismann holds his own explanation to be the only conceivable explanation. 'For there are only two possible a priori explanations of adaptations for the naturalist, namely, the transmission of functional variations and natural selection' (loc. cit., p. 336) ; 'but as the first of these can be excluded' (on account of the infertility of workers and soldiers), 'only the second remains.'

But are the alternatives really only as Weismann suggests? Is there no choice left for the naturalist?

When I was reading his All-sufficiency of Natural Selection, kindly sent me by the author, it came into my mind that I could not accept his dilemma. For the different individuals in the insect states may be explained in a third way-in a way overlooked by Weismann. This third explanation is nothing more than the subject of all this treatise of mine. It is that, in obedience to different external influences, the same rudiments may give rise to different adult structures.

I am glad that the same answer has been made to Weismann's All-sufficiency of Natural Selection by two biologists, Herbert Spencer and Emery, simultaneously with mine. Emery, a specialist upon the structure of ants, and Herbert Spencer, relying upon the investigations of sereral Englishmen, have sought to prove that the differences between the individuals in the colonies of ants, 
bees, and termites, have been slowly called into existence by the operation of external influences affecting the egg in its situation and food during development.

It has been shown fully by experiment and by observation that the fertilised eggs of the queen bee may become either workers or queens. This depends merely on the cell in the hive in which the egg is placed, and on what food the embryo is reared. In the specially large cells, known as queens' chambers, and with specially nutritious diet, they become queens. With poor food, and in smaller cells, they become workers. Even if worker larvæ be supplied in time with a richer diet, they may be turned into queens.

Similarly, the differences that exist among termites and ants, as Emery shows, may be described as polymorphism due to food. The Italian zoologist, Grassi, has shown that termites have it in their power to alter the relative numbers of workers and soldiers, and to produce as many of the latter as may be required, and they are able to accelerate the sexual maturity of other individuals by supplying nourishment suitable for stimulating the maturation of the genital organs.

Emery explains this polymorphism by attributing it to the general laws of growth in the insect organism under the influence of different external stimuli. He thinks that 'the production of workers depends upon a special capacity of the germplasm to respond to the abundance or scantiness of certain nutritive materials by a greater 
growth of certain parts of the body, and a lesser growth of other parts. Workers' food stimulates growth in the jaws and brain, retards growth in the wings and sexual cells. Queens' food has the opposite action.' There is a correlation between retardation of the sexual glands and acceleration of the development of the head, just as in vertebrates there is a correlation between the sexual glands and the secondary sexual characters. "The characters by which the workers differ from the queens, therefore, are not innate, but are produced secondarily.'

Quite independently, but simultaneously, Herbert Spencer has suggested the same explanation as Emery. Moreover, he has used the conditions that exist among the state-forming insects as a strong argument against Weismann's doctrine of determinants. The observations of many careful persons, such as Charles Darwin, Emery, and others, show that in many species of ants the extreme types of individuals are connected by many intermediate forms. (Apud Emery, this is the case in many Myrmicidce, in most Camponotidce, and in Azteca.) These forms are transitional, not only in general size, but in the degree to which the genital organs have been arrested, and in the peculiarities of the jaws.

Spencer explains these transitional forms, and I agree with him, by supposing that the stoppage in food supply has taken place at different times after development has begun. ("It must happen that the stoppage of feeding will be indefinite.') Thus, 
the existence of transitional forms presents no difficulty on the theory of the agency of food. But how can the doctrine of determinants be applied to it? 'If he is consistent' (says Spencer, Contemporary Review, lxiv., p. 901), ' he must say that each of these intermediate forms of workers must have its special set of "determinants," causing its special set of modifications of organs ; for he cannot assume that while perfect females and the extreme types of workers have their different sets of determinants, the intermediate types of workers have not. Hence we are introduced to the strange conclusion that, besides the markedly distinguished sets of determinants, there must be, to produce these intermediate forms, many other sets slightly distinguished from one another-a score or more kinds of germplasm, in addition to the four chief kinds. Next comes an introduction to the still stranger conclusion, that these numerous kinds of germplasm producing these numerous intermediate forms are not simply needless, but injuriousproduce forms not well fitted for either of the functions discharged by the extreme forms, the implication being that natural selection has originated these disadvantageous forms. If, to escape from this necessity for suicide, Professor Weismann accepts the inference that the differences among these numerous intermediate forms are caused by arrested feeding of the larvæ at different stages, then he is bound to admit that the differences between the extreme forms, and between these and perfect females, are similarly caused. But if he 
in does this, what becomes of his hypothesis that the several castes are constitutionally distinct, and result from the operation of natural selection?'

My course of thought leaves me with little to add to this criticism by Spencer. In this case, as in many others that I have pointed out, Weismann makes his usual mistake. He incorporates in the rudiment what really are stimuli coming from external conditions during the process of develop-ment; he makes a grave confusion between the rudiment and the conditions of its development.

c. In my view, in these cases of polymorphism in the colonies of insects Nature exhibits a series of most important experiments, and their plain meaning is that the same germinal material, when subjected to different external influences, may produce very different final products. When from the neutral germinal material of an insect egg there is produced a male or female creature, or a worker or. soldier (as this or that influence acts), the process is no other, and presents no greater difficulties, than when an experimenter, taking the young bud of a plant, according to the conditions to which he subjects it, can turn it into a vegetative or into a reproductive shoot, a thorn or a root; po different to what occurs when the investigator, cutting into a Cerianthus, produces a second or third mouth, surrounded by tentacles, or in the case of Cione surrounded by eye-spots.

It has been shown, I think, in these pages that much of what Weismann would explain by determinants within the egg must have a cause outside 
the egg. The chief factors in the process of derelopment we have found to be: (1) The multiplication of cells by division (growth as a moulding factor); (2) the relations of cells to their external environment (position in its widest sense as a factor); (3) the interrelations of the parts of a whole (cells, tissues, and organs) to one another and to the whole (correlative development). There remains to be considered the extent to which the germinal material in the egg determines the course of development of the organism. Here, before all things, it must be insisted that the individual nature of the cell determines the specific fashion in which the cell will react to the varying stimuli coming from varying conditions. The same agency produces very different results upon different organisms. These differences must be attributed to the differences in the nature (different intimate structure) of the active material.

Sachs speaks strikingly on this point (Physiology of Plants, p. 602): "If the same external cause induces exactly opposite effects in the organs, the explanation of this must simply be sought in the different structure of the organs. If one organ, when illuminated from one side, becomes curved so as to be concave on the side turned towards the centre of light, while another becomes convex on that side, the cause can only lie in the internal structure of the organ. But it is just on such differences of structure that the great variety of reactions which the most different plant organs exhibit towards the same external influences 
depends; and, fundamentally, all that we term biology - the mode of life of organisms-depends upon the fact that different organisms react differently towards the same external influences, and these reactions differ not only qualitatively, but also quantitatively, the finest gradations existing in both cases.'

For instance, in a plant-embryo roots are produced at the lower end under the influence of the soil and of gravity. But it is upon the specific nature of the protoplasm of different kinds of plants that the special shape of the whole root system depends: whether, for instance, the root system ramifies superficially or strikes deep into the soil; whether the rootlets grow quickly or slowly; in what fashion they fork, and whether or no they form special structures like bulbs.

Thus, even from my point of view, explanation of the process of development requires the assumption of the existence of different kinds of germinal material in different kinds of organisms. These germinal substances must be possessed of an extraordinarily complex organisation, and must be able to react in specific fashion-that is to say, in a fashion different in each species-to all the slightest internal and external stimuli encountered from time to time as the organisation becomes formed by cell division.

In this sense I agree with what Naegeli says :

- The egg-cells contain all actual specific characters as truly as the adult organisms; when they exist in the condition of eggs, organisms are as 
distinct from each other as in the adult condition. The species is present as truly in the fowl's egg as in the fowl, and the egg of a fowl differs as much from the egg of a frog as the fowl differs from the frog. Men, rodents, ruminants, invertebrates display more or less important and outwardly visible differences in constitution; so also the sexual cells to which they give rise, since they represent the rudiments of the future adults, must be different from each other in the constitution of the rudiments, although we are not yet able to prove these differences by observation.'

In this assumption of a specific and highlyorganized germinal substance with which a development begins, I agree with evolutionists; but in its details my conception is quite different from their conception. For I can ascribe to the germinal substance only such characters as are appropriate to the true nature of a cell, but I cannot ascribe to it the numerous characters that can come into existence only by the interrelations of many cells and the action of the environment.

Haacke, in his recently-published book (Gestaltung und Vererbung), has expressed a doubt that my conception of development is, after all, a preformational theory. 'For preformation,' he says, ' it is not necessary to imagine that the egg contains a miniature of the adult. If only, like Hertwig, one assumes to be present in the germinal material a prearrangement of qualitatively different idioblasts, one has steered into the harbour of preformation with all sails set.' 
In reply, I plead that, like Naegeli, De Vries, Driesch, and others, I have tried to blend all that is good in both theories. My theory may be called evolutionary, because it assumes the existence of a specific and highly-organised initial plasm as the basis of the process of development. It may be called epigenetic, because the rudiments grow and become elaborated, from stage to stage, only in the presence of numerous external conditions and stimuli, beginning with the metabolic processes preceding the first cleavage of the egg-cell, until the final product of the development is as different from the first rudiment as adult animals and plants differ from their constituent cells.

To explain more clearly my conception of the nature of the process of development, especially in the relations that I conceive to exist between the rudiment and the adult, I shall conclude by reverting to my comparison between a human community and an organism.

As a man arises from an egg-cell by cell multiplication and cell differentiation, so the human community, a composite organism of a still higher nature, has arisen from separate human beings as its starting-point.

Culture and civilization are the wonderfully complicated results of the co-operation of many individuals united in society. By the manifolding of their relations and their combinations, men in society have brought about a higher complexity than man, left by himself, ever would have been able to develop from his own individual properties- 
a complexity that has arisen by the interaction of the same characters of many men in co-operation.

Similarly the activity of the egg in growth and cell-formation is an inexhaustible source of new complexity; for the self-multiplying systems of units, always binding themselves into higher complexes, continually enter into new interrelations, and afford the opportunity for new combinations of forces-in fact, of new characters.

Both cases-the course of the development of the egg-cell into a man, and of men into a statedepend upon epigenesis, not upon evolution.

The comparison may be carried into details.

The more complex and higher organisation of human society occurs in this fashion: of the numerous single individuals, all of which are endowed with the various incipient human characters, some individuals elaborate some incipient characters, others other characters, and these come to play correspondingly different parts. The special differentiation undergone by any individual depends upon the special place he comes to occupy in the whole of which he is a part, not upon really different organisation residing in him from his birth. Beside those characters which have developed specially in his case, there lie dormant the rudiments of all the characters possessed by men, and, under different conditions, these might have come to development.

Differentiation in multicellular organisms takes a similar course. Every cell, by doubling division of the egg, receives all the rudiments of its kind; 
of these rudiments, some in one set of cells, others in another, come to develop, according to the part of the whole in which the cells come to lie during the progress of the developrnent, and according to the relations to the whole they come to assume. Thus, here they assume the characters of the external skin; there, they become gland-cells of the intestine ; here, muscle-fibres; there, sense-cells or nerve-cells ; in one place they serve the whole organism, in the form of blood-corpuscles, as agents for nutrition and respiration; there, becoming connective tissue or bone, they form skeletal elements of the body.

Thus, during the course of development, they are forces external to the cells that bid them assume the individual characters appropriate to their individual relations to the whole; the determining forces are not within the cells, as the doctrine of determinants supposes. The cells develop those characters that are suggested by their relation to the external world and their places in the whole organism.

But I must insist here that the subordination of the cells to the whole organism, in both multicellular animals and in plants, is much more complicated than that of the units to the human state. In the latter case, the individuals are separate from one another; they are independent organisms and are bound together only in social relations. None the less, consider how in a civilized state the apparently sovereign individual is conditioned in all his circumstances; how each change in the general state exercises an influence on the individual's disposition freedom of will, and method of life (dwelling, 
food, institutions, health); then reflect how much greater in the animal and the plant is the domination of the whole, and the subordination of the units, as in them cell is directly joined to cell-indeed, in most cases united materially by threads of protoplasm. In such cases the self-sufficiency of the cell as an elementary, living organism is so far prevented, that it becomes a subordinate part, with its function in dependence on the whole.

One other point our comparison will make clearer: I refer to the relation of the specific nature of the rudiment to the specific nature of the product of the rudiment.

The different organisations and qualities of the communities formed by different animals may be explained by the special characters of the animals forming them. Those of the bee colonies depend on the nature of bees; of ant colonies on the nature of ants; of the societies of men on the nature of men; indeed, in the latter case we see how they differ as they are formed by Italians, Germans, Slavs, Turks, Chinese, or Negroes. Similarly, the specific organisation of the cell determines the kind of animal which may be built up by it.

In my theory two assumptions of totally contrasting nature are made: I assume a germplasm of high and specific organisation, and I assume that this is transformed into the adult product by epigenetic agencies. To a certain extent, therefore, I reconcile the opposition between evolution and epigenesis, these opponents so prominent last century. But my theory does not pretend to explain all 
the many problems involved in the course of organic development. In this respect it differs from Weismann's doctrine of determinants, as that is a closed system, finding within itself a formal explanation of all development. So far it seems to me an abandonment of explanation rather than an explanation; for it explains by signs and tokens that elude verification and experiment, and that cannot encounter concrete investigation. His explanation is no more than a description, in other words, of the visible events of development. To be more than this, it would be necessary to explain how in each case the biophores and determinants and ancestral plasms are constituted, and how they are arranged in the architecture of the germplasm so as to produce the development of the egg-cell in this or that fashion. It must, at the least, offer such possibilities as the structural formulæ of chemists offer. But in the present stage of our knowledge Weismann's method is unpromising; it merely transfers to an invisible region the solution of a problem that we are trying to solve, at least partially, by investigation of visible characters; and in the invisible region it is impossible to apply the methods of science. So, by its very nature, it is barren to investigation, as there is no means by which investigation may put it to the proof. In this respect it is like its predecessor, the theory of preformation of the eighteenth century. 


\section{INDEX AND GLOSSARY}

\section{A}

Acineta, a group of protozoa, development of, 41 .

Acquired characters, question of their inheritance, $x$.

Amphioxus, a marine animal, representative of the primitive vertebrate stock, experiments on eggs of, 61 .

Anabolism, the formation of more complex chemical bodies by the agency of protoplasm, 86.

Animal cells, characteristic mode of growth, 111.

Antennularia, Loeb's experiment, 117.

Ants, polymorphism in, 125.

Ascidians, tunicate animals, 46.

Atavism, the occurrence in an organism of a character abnormal in it, but normal in an ancestor, 24.

\section{B}

Bees, polymorphism in, 125 . Beetroot, grafting experiments, 121.

Begonia, reproduction from leaves, 46.

BERT, experiments on rats, 73 . Beresowsky, skin-grafting, 75. BEYERINCK, upon galls, 51.

Biophores. Each determinant, according to Weismann, is composed of a number of ultimate living pieces, the biophores, which are the active agents that direct the functions of a mature cell, ix, 22.

Blastosphere, an early stage in embryonic development; the embryo consists of a hollow sphere, the walls of which consist of a single layer of cells, and the cavity of which is called the segmentation cavity, xvii; explanation of formation, 97, 98 .

Blood, transfusion of, 75 .

Blumenbach, nisus formativus, 5 ; upon galls, 50 .

Bone-grafting, 73,74 .

Bonellia, sexual dimorphism in, 122.

Bryozoa, a group of minute animals which form encrustations on seaweeds and stones, 46.

Buds, origin of, 28 ; reproduction and regeneration by, 46 .

\section{C}

Cell, description of, 31 ; characters possible in, 88; differentiation of, in development, 112 ; as units in morphology and physiology, 113; Sachs on, 114; Vöchting on, 114, 116.

Cell theory, relation of, to heredity, 31.

Centrosome, an organ of cells 
most obvious during nuclear division, 93.

Cerianthus, experimental heteromorphoses, 51.

Chabry, destruction of segmentation sphere, 62 .

Chromatin, a material found in the nucleus of cells, so called because it absorbs stains with avidity: germplasm and, viii, xiv; relation of, to specific character of cells, 36, 37.

Chromosomes, definite, visible bodies, as which the chromatin of a dividing nucleus appears, xiv, 93.

Crystal, growth of, compared with organic growth, 108.

Cione, experimental heteromorphoses, 52.

Clavellina, reproduction from buds, 46 .

Cleavage - planes, the planes separating the daughternuclei, or daughter-cells, in the early division of a fertilised egg-cell, xvii ; relation between appearance of, and structure of eggs, 95.

Cœlenterata, a major division of multicellular animals, including such creatures as sea-anemones, corals, and jelly-fish, 46.

Continuity of the germplasm, 26.

Continuity of life, the doctrine opposed to spontaneous generation, 2.

Correlations, 118, 121.

D

DARwIN, pangenesis, 21.

Determinants. Each id of germplasm is supposed by Weismann to be composed of minor pieces, arranged in a complicated fashion that is the result of the past history of the species. For every part of the body, large or small, that may be different in different individuals or species, there is, at least, one determinant in the $i d$. The determinants are so grouped in the $i d$ that they are liberated and become active when the time comes for the development of that part of the body they control, viii, 22; arguments against, 82 ; relation to cells, 87.

Determinates, the smallest parts of an organism which vary independently, and which are supposed by Weismann to be represented in the germplasm by special pieces, 23, 25.

Differentiating division, such a division of the nucleus as would result in daughternuclei unlike each other, and unlike the parent nucleus. The qualities of the parent nucleus are supposed to have been distributed between the daughter-nuclei, xi ; absence of visible evidence for, $\mathrm{xv}$, 25 ; objections to occurrence of, 34,78 .

Dimorphism, the appearance of the same species in two different forms, sexual dimorphism, 122, 124.

Disharmonic union in grafting, 70. 
Double monsters, as examples of heteromorphosis, 63.

Doubling division. When an amœeba reproduces by simple division, the daughter-amœbæ are identical, and each is identical with the parent except in size; from one amœba two have been formed. A doubling division of the nucleus is such as would result in the formation of two nuclei alike in every respect, ix; visible evidence for, $\mathrm{xv}, 24$; in unicellular organisms, 40; occurrence of, with differentiating division, 78.

DrIEsCH, experiments on eggs, 54 ; separation of segmentation spheres, 60.

\section{E.}

Echinoderms, a group of marine animals, of which the starfish is the most familiar type, eggs of, 54 .

Echinoidea, a group of echinoderms, 61.

Ectoderm, the tissue in an adult derived from the epiblast (which see), 19.

Egg, relation between structure and division of, 94 ; specific character of, 135.

EMERY, on polymorphism in ants, 128.

Endoderm, the tissue in an adult, derived from the hypoblast (which see), 19.

Enfoldment. See Evolution.

Epiblast. In the development of all multicellular animals, the young embryo soon becomes divided into two sets of cells, the epiblast and hypoblast ; where a gastrula is formed, the outer layer of cells is the epiblast, the inner layer the hypoblast, xviii.

Epigenesis, the doctrine that the formation of a new individual is not the mere outgrowing of particles hidden in the egg-cell, but the result of moulding external forces, xiii ; Roux's definition of, 7 ; Weismann's denial of, 9; epigenetic explanation of stages in development, 98; summary of Hertwig's acceptance of, 136.

Evolution. Originally the term was applied, not to the origin of existing forms of life from common ancestors, but to the doctrine that every living creature contained within it the whole series of its future descendants, and that the growth of a living creature was evolv. ing of one of these enfolded miniatures, xiii, 1, 2, 3 ; Roux's contrast of, with epigenesis, 6 ; the new evolution, 10 ; Hertwig's partial agreement with, 135, 136.

Experiment, WVeismann's caution against, 10 .

\section{F.}

Fertilisation, the union of the nuclear matter of a male cell with the nuclear matter of a female cell, xii, xiv.

Foraminifera, a group of protozoa provided with shells, 44.

Fored, on eyes of ants, 126. 
Frogs' eggs, Hertwig's experiments upon; development of, under compression, 57-60.

Funaria, reproduction from chopped pieces, 46 .

\section{G.}

Galls, 50.

Gastrula, an early embryonic stage, most simply formed from the blastosphere by the invagination of one side of the wall, and consisting of a hollow sac, the walls of which are formed by two layers of cells, xviii, 60 ; formation of, 99.

Gemmules. See Pangenesis.

Germ, the youngest embryonic stage of an individual or organ, 10.

Germplasm, the substance supposed to be the material bearer of inherited qualities: Weismann's conception of, viii, 20 ; identification of, with nuclear matter, 21; account of Weissmann's theory, 21-28.

Germ-tracks, the hypothetical paths along which germplasm passes in an unaltered condition during development, 27 ; objections to, 81.

GOEBEL, on plasticity of plants, 120.

Grafting, 68, 70 ; of Hydra, 72; bone-grafting, 73, 74; skingrafting, 74, 120, 121.

Grassi, polymorphism due to food, 129.

Gregarines, a group of parasitic protozoa, development of, 41.
H.

HAACKE, declaration that Hertwig is evolutionary, 135.

Hæmoglobin, the red colouring matter of blood, 75 .

Harmonic union in grafting, 70.

Heteromorphosis, explanation of, 49 ; cases of, 51,52 ; embryonic cases, 54.

His, presence of foci in the germ, 13.

Histogenous, producing microscopical characters, 20.

Histology, study of the microscopical characters of cells and tissues, differentiation, 115.

Hydatina, determination of sex, 5 ; temperature, 123.

Hydra, regeneration in, 47; grafting of, 72 .

Hydromedusæ, a group of invertebrate animals, the typical members of which are branched colonies of polyps: Weismann's investigations on, viii, xii.

Hypoblast. See Epiblast, xvi. Hypotrichous infusoria, a group of protozoa, 41 .

\section{I}

$I d s$, hypothetical individual pieces, a number of which are supposed by Weismann to be present in the germplasm of every sexual cell, and each of which is supposed to contain the inherited material necessary for a complete new organism. It has been suggested that tiny beads seen within the chromosomes of 
a sexual cell are the $i d s$, viii, $23,33$.

Idioblasts, Hertwig's name for hypothetical ultimate units of living matter, 22, 32; the ultimate units of living matter, according to De Vries, 22.

Idioplasm, as opposed to germplasm, which is the nuclear material of germ-cells ; idioplasm is the nuclear material of tissue-cells, xi, 38 .

Immortality, definition of, 82 ; of germ-cells, ix ; of unicellular organisms, 17 ; of germ-cells, 80 .

Individuality of cells, 115.

Invagination, the infolding of a layer of cells, as, for instance, in the transformation of a blastosphere into a gastrula, xvii.

Isotropism, explained in footnote, 33 .

\section{K}

Karyokinesis, a complicated process of nuclear division, xiv.

Katabolism, the formation of less complex chemical bodies by the agency of protoplasm, 86.

\section{L}

Labile, unstable, constantly changing, 38.

LANDOIS, experiments on transfusion of blood, 75 .

Leibnitz, on immortality, 82.

LoEB, on heteromorphoses, 49 ; on plasticity of animals, 117 .
M

Maupas, experiments on sex of rotifers, 123.

Melons, determination of sex by temperature, 124 .

Mesoblast, in the development of the colomata, or threelayered multicellular animals; a third set of cells, the mesoblast, arises between the epiblast and hypoblast, xviii.

Monsters, relation of, to division of egg-cell, 63 .

Mosaic theory of Roux, 56 .

Morphoplasm, the general protoplasm of a cell, 35 .

Multicellular organisms, those in which the body is composed of many cells, specialized in different directions ; cell-division in, 43.

Mus, experiments on grafting among mice and rats, 74 .

Myxomycetes, sometimes called ' slime fungi,' a group of low organisms, consisting of creeping masses of proto. plasm with many nuclei, 33.

\section{$\mathrm{N}$}

Naegeli, biological units, 30 ; cross-fertilization and grafting compared, 69 ; heredity, 92 ; environment in development, 104 ; on plasticity of plants, 119; on specific characters of eggs, 134.

Nais, regeneration in, 47 .

Notochord, formation of, from unusual cells, 117.

Nucleus, a specialized portion of the protoplasm of cells, different in chemical and 
physical properties (see Chromatin, Chromosomes), as the bearer of heredity, 19 . Nussbaum, views on origin of germ-cells, 17.

Nutrition, influence of, on development, 2.

\section{$\mathrm{O}$}

OLlier, bone-grafting, 73 .

Ontogeny, the development of an individual from the egg upwards, 9.

Osteoblasts, cells which are the active agents in bone-formation, 73.

Ovogenesis, the formation of egg-cells in the ovary, 13.

\section{$\mathrm{P}$}

Pangenesis, Darwin's provisional hypothesis, that the sexual cells were composed of minute particles (gemmules), given off by all the cells of the body, 21 .

Periosteum, a cellular sheath of bones, 73 .

Physiological units, Herbert Spencer's name for hypothetical ultimate units of living matter, 22.

Pistachio, influence of temperature on, 121.

Plant-cells, mode of growth, 110.

Plasomes, Hertwig's name for theoretical units of protoplasm, 32.

Plasticity of plant tissues, 117, $119,120$.

Pluteus, a free-swimming larval stage in the development of echinoderms, 54 .

Podophrya, reproduction of, 41 .
Polymorphism, the appearance of the same species in several different forms in ants and social insects, 125.

Ponfick, on transfusion of blood, 75.

Preformation, identical with the original meaning of evolution, which see.

Prothallus, the leaf-shaped green organism that grows from the spore of a fern and produces sexual organs, 49 .

Pseudopodia, extensions of protoplasm beyond the general contour of the cell, 41 .

\section{$\mathrm{R}$}

Radiolaria, a group of protozoa, 44.

Regeneration in plants and animals, 45,47 .

Rhipsalis grafted on Opuntia, 71.

Roux, contrast between epigenesis and evolution, 6 ; mosaic theory of, 56 .

Rudiment, used here as a translation for the word anlage, which means the first plotting-out or beginning of a living structure. Darwin showed that rudimentary organs in adult creatures were for the most part vestiges of organs that had lost their use. In this treatise 'rudiment' is applied to an organ or structure in its incipient condition, whether that incipient state be visible in a young embryo, or a hypothetical structure in the germplasm, 6 ; latent rudiments, 37. 


\section{S}

SAchs, on cells, 114 ; on reaction and protoplasm, 133. Salix purpurea, reproduction from galls, 51 .

Schnitт, bone-grafting, 74 .

Segmentation, the early division of a developing egg, xvii.

Segmentation spheres, the cells resulting from the early divisions of a developing egg, separation of, by Wilson and Driesch, 60.

Segmentation cavity. See Blastosphere.

Sex, determination of, by temperature, 123, 124.

Sexual cells (spermatozoa in male, ova or egg-cells in female), the nucleated pieces of protoplasm which are the starting-point of the new generation in sexual reproduction, origin of, 18.

Soma, the body of a plant or animal as contrasted with the reproductive cells contained within it, 45.

Somatic cells, the cells of the soma ; mortality of, 17.

Spencer, Herbert, controversy with Weismann on polymorphism in insects, 125.

Spermatogenesis, the formation of spermatozoa in the testis, 13.

Spontaneous generation, 2.

Stolon, a strand of tissue connecting the individuals of colonial animals, 46 .

Strasburger, the value of the nucleus in heredity, 13, 18.
$\mathrm{T}$

Termites, polymorphism in, 125.

Transfusion of blood, 75 .

Transplantation of bone, 73, 74.

Trembley, grafting of Hydra, 72.

Triton, an amphibian, experiments on the egg by constriction, 64 .

Tubularia, experimental heteromorphoses, 51.

Tunicata, a group of marine animals clad with a leathery tunic, 14.

\section{U}

Unicellular organisms, animals (protozoa) and plants (protophyta) with the simplest structure, each being a single cell : immortality of, 17 ; division doubling in, 40 .

Unit, definition of a biological, 30.

\section{V}

Vegetative affinity, 66 et seq .

Vertebrates, regeneration of lost parts, 47.

Voechting, experiments on grafting, 70 ; harmonic and disharmonic union, 70 ; on cells, 114,116 ; on plasticity of plants, 117, 119; on grafting, 120.

\section{TV}

WeIsurans and preformation, 8-10 ; caution against experiment, 12; sources of his theory, 20, 21; Hertwig' description of his theory, 22 
absence of proof for differentiating division, 34 ; symmetry of egg and adult, 55 ; immortality of germ-cells, 17, 80, 82 ; germ-tracks, 83 ; doubling division, 102 ; controversy with Spencer, 125. Willow, reproduction from slips, 46.

Wilson, separation of seg- mentation spheres of amphioxus egg, 60.

WolfF, Theoria Generationis, 4.

Wounds, healing of, in relation to idioplasm, xii.

Y

Yolk, nutritive material stored in an egg-cell, xvi.

THE END. 


